Ks. Mariusz TERKA*

\title{
WIARA JAKO POSZUKIWANIE BOGA W ŚWIETLE NAUCZANIA ŚW. AUGUSTYNA
}

Św. Augustyn, rozmyślając nad zjawiskiem wiary, wyróżnia w niej rozmaite, choć zależne od siebie poziomy. Zawiera się w niej przekonanie o istnieniu Boga, przyjęcie określonej prawdy, zaufanie temu, kto ją odsłania oraz osobista relacja istniejąca pomiędzy tym, kto wierzy a tym, komu się wierzy ${ }^{1}$. Wiara posiada więc wymiar doktrynalny, ale wymaga również zaangażowania egzystencjalnego; podaje swe prawdy jako pewne i niezmienne, lecz jednocześnie towarzyszy jej pewien brak poznania; pozwala poznać o Bogu więcej niż można pojąć posługując się jedynie siłami intelektu, a zarazem chroni Jego tajemnicę, nie dostarczając wystarczających argumentów i każąc rozumowi jedynie wierzyć. W wierze zawarty jest zatem pewien paradoks, który sprawia, że dla biskupa Hippony jest ona nie tyle kresem poznania Boga, ile początkiem drogi, na której należy Go poszukiwać, gdyż pewność wiary budzi pragnienie zobaczenia tego, w co się wierzy ${ }^{2}$.

Poszukiwanie Boga zawiera więc w sobie wszystkie aspekty wiary i wyjaśnia je, ale z tego właśnie powodu samo również wymaga objaśnienia. Wydaje się zatem, że rzeczą konieczną dla zrozumienia zjawiska wiary i możliwości jej zaistnienia, jest ukazanie jej wewnętrznej struktury oraz mechanizmów, jakie w niej działaja, otwierając człowiekowi możliwość poszukiwania Boga. Wydaje się bowiem, że dopiero $w$ ich świetle możliwe jest zrozumienie zawartego w wierze paradoksu i połączenie wymiaru doktrynalnego z egzystencjalnym zaangażowaniem. W celu wyjaśnienia tych kwestii należy jednak pójść śladem biskupa Hippony, który własne myślenie o wierze zmierzające do wyjaśnienia jej istoty i genezy, zaczyna od analizy danych świadomości podmiotu poznającego, jakim jest człowiek, by następnie odsłonić ją jako drogę prowadząca poprzez doczesne znaki do odkrywania niewidzialnego Boga. Ponieważ jednak wiara nie jest jedynie sprawą poznania, lecz wyraża się w egzystencjalnej

* Ks. dr Mariusz Terka - wykładowca patrologii w Wyższym Instytucie Teologicznym w Częstochowie; e-mail: mariuszterka0@op.pl.

${ }^{1}$ Por. E. TeSelle, Fede, w: Agostino Dizionario Enciclopedico (= ADE), ed. A. Fitzgerald, ed. italiana L. Alici - A. Pieretti, Roma 2007, 714-717.

${ }^{2}$ Por. Augustinus, De Trinitate IX 1, 1, ed. A Trapè, NBA 4, Roma 2003, 504-506, thum. M. Stokowska: Św. Augustyn, O Trójcy Świętej, POK 25, Poznań 1962, 277-278; tamże XV 28, 51, NBA 4 , 716-718, POK 25, 458. Zob. S. Jaśkiewicz, Św. Augustyn - poszukiwanie Boga, Katowice 2012, 95. 
relacji człowieka z Bogiem, to rzeczą konieczną będzie również określenie mechanizmów funkcjonujących w jej wnętrzu, a szczególnie określenie jej istoty w świetle działania Boga, którego objawianie się umożliwia zaistnienie owej relacji. Ze względu na obszerną tematykę podejmowanego zagadnienia w niniejszym artykule należy uwzględnić szeroki zakres materiału źródłowego uwzględniający zarówno wczesne pisma św. Augustyna, jak również jego dojrzałe prace teologiczne, ze szczególnym uwzględnieniem jednego z jego podstawowych dzieł, czyli $O$ Trójcy Świętej, w którym znaleźć można wiele ścisłych analiz dotyczących zagadnienia wiary.

\section{FENOMEN WIARY}

Akt wiary dany jest ludzkiej świadomości w sposób bezpośredni. Człowiek spostrzega ją wówczas, gdy zwracając się ku swemu wnętrzu, rozumie siebie jako kogoś wierzącego lub niewierzącego. Wiedza ta nie przychodzi do niego ze świata zewnętrznego i nie jest zdobywana poprzez pośrednictwo zmysłów, w sposób, w jaki poznaje się rzeczy materialne lub - w ograniczonym zakresie - drugiego człowieka, lecz jest rozpoznawana jako rzeczywistość duchowa, dostępna dla rozumu. Owa samoświadomość, która widzi w sobie wiarę bądź niewiarę, jest wiedzą najpewniejszą (certissima scientia), bo choćby nawet nie istniał żaden przedmiot, o którym ona mówi albo wyobrażenie o nim było uwikłane w błąd, to jednak zawsze wiemy, że wierzymy lub mamy świadomość własnej niewiary³.

Ponieważ akt wiary jest czymś, co rozgrywa się we wnętrzu człowieka, to każdy wierzący może nazywać ją swoją własną wiarą. Nie oznacza to jednak tego, że jest ona jedynie indywidualnym i niemożliwym do zakomunikowania doświadczeniem. Chociaż bowiem nikt nie potrafi dostrzec wiary w innym człowieku, a jedynie może się domyślać jej istnienia na podstawie analogii do własnej wiary lub na podstawie zewnętrznych czynów, jakie ona rodzi, to jednak jest ona czymś, co odsyła człowieka poza siebie samego. Jest to możliwe, gdyż ujęty fenomenologicznie akt wiary odsłania się jako zjawisko o charakterze intencjonalnym. Kieruje się więc on ku jakiemuś przedmiotowi i zawiera treść odnoszącą się do rzeczywistości wewnętrznej lub świata zewnętrznego, co oznacza, że wykracza on już poza sferę li tylko podmiotową.

Przedmiotem wiary jest więc coś, czego - jak podkreśla św. Augustyn - nie można zrozumieć, choć nie musi to być rzecz niepoznawalna sama w sobie.

${ }^{3}$ Por. Augustinus, De Trinitate XIII 1, 3-4, NBA 4, 504-508, POK 25, 350-351. Świadomość niewiary zakłada jednak jaką́s wcześniejszą wiedzę o tym, czym jest wiara, by móc jej następnie zaprzeczyć. Wydaje się zatem, że niewiara jest pochodną wiary i dlatego opisywana jest przez św. Augustyna przede wszystkim w sposób negatywny, tzn. jako odrzucenie Boga.

${ }^{4}$ Por. tamże XIII 2, 5, NBA 4, 510, POK 25, 353. 
Wystarczy bowiem, by $\mathrm{w}$ danej chwili nie było możliwe jej poznanie ${ }^{5}$. W związku z tym Hippończyk pisze:

„Są trzy rodzaje rzeczy będących przedmiotem wiary. Jedne to takie, w które zawsze się wierzy, lecz nigdy ich nie rozumie. Taka jest cała historia traktująca o sprawach ludzkich i przemijających. Drugie to takie, które się pojmuje zaraz po tym, jak się w nie uwierzy. Tak jest ze wszystkimi rozumowaniami ludzkimi dotyczącymi czy to matematyki, czy to jakichkolwiek innych dyscyplin. Trzeci to rodzaj rzeczy, w które najpierw się wierzy, a potem je rozumie. Takie są zagadnienia dotyczące spraw boskich: pojęć je mogą tylko ci, co mają czyste serce"6.

To, w co się wierzy, może być zatem obecne zarówno w zdarzeniach teraźniejszych, przeszłych, jak i przyszłych ${ }^{7}$ a także mieć różną jakość pod względem aksjologicznym, dobrą lub złą. Wiara może odnosić się do podmiotu poznającego lub dotyczyć innych ludzi, gdyż - jak podkreśla Hippończyk - każdy wierzy, że w pewnym momencie czasowym zaczął istnieć i nie jest wieczny ani on sam, ani pozostali ludzie ${ }^{8}$. Przybiera ona zatem postać wiary w coś oraz uwierzenia komuś, kto dla człowieka wierzącego staje się wówczas świadkiem lub godnym zaufania autorytetem. Św. Augustyn podkreśla, że obdarzony jest nim przede wszystkim Bóg, który przemawia przez Pismo Święte i Kościół oraz przez poszczególnych świętych chrześcijan ${ }^{9}$.

${ }^{5}$ Por. tenże, De agone christiano 13, 14-15, PL 40, 299, tłum. W. Budzik: Św. Augustyn, Walka chrześcijańska, w: Św. Augustyn, Pisma katechetyczne, Warszawa 1952, 241; tenże, De catechizandis rudibus 26, 50, ed. I.B. Bauer, CCL 46, Turnholti 1969, 173-174, tłum. W. Budzik: Św. Augustyn, Poczatkowe nauczanie religii, w: Św. Augustyn, Pisma katechetyczne, s. 56; tenże, De civitate Dei XXI 5, ed. B. Dombart-A. Kalb, CCL 48, Turnholti 1955, 764-766, tłum. W. Kubicki: Św. Augustyn, Państwo Boże, Kęty 2002, 863-865.

${ }^{6}$ Tenże, De diversis quaestionibus octoginta tribus 48, ed. A. Mutzenbecher, CCL 44A, Turnholti 1975, 75: „Credibilium tria sunt genera. Alia sunt quae semper creduntur et numquam intelleguntur, sicut est omnis historia temporalia et humana gesta percurrens; alia quae mox ut creduntur intelleguntur, sicut sunt omnes rationes humanae vel de numeris vel de quibusque disciplinis; tertium quae primo creduntur et postea intelleguntur, qualia sunt ea quae de divinis rebus non possunt intellegi, nisi ab his qui mundo sunt corde”, tłum. I. Radziejowska: Św. Augustyn, Księga osiemdziesięciu trzech kwestii, Kęty 2012, 87.

${ }^{7}$ Por. tenże, De Trinitate XIII 2, 5, NBA 4, 510, POK 25, 353.

${ }^{8}$ Por. tenże, Enchiridion ad Laurentium sive de fide, spe et caritate II 8, ed. E. Evans, CCL 46, 51-52, tłum. W. Budzik: Św. Augustyn, Podręcznik dla Wawrzyńca, czyli o wierze, nadziei i miłości, w: Św. Augustyn, Pisma katechetyczne, s. 81-83.

${ }^{9}$ Por. tamże I 4, CCL 46, 49-50, thum. Budzik, s. 79; tenże, De quantitate animae VII 12, PL 32, 1041-1042, thum. D. Turkowska: Św. Augustyn, O wielkości duszy, w: Św. Augustyn, Dialogi i pisma filozoficzne, t. 2, Warszawa 1953, 120; tenże, De ordine II 5, 16, ed. W.M. Green, CCL 29, Turnholti 1970, 115-116, tłum. J. Modrzejewski: Św. Augustyn, O porzqdku, w: Św. Augustyn, Dialogi i pisma filozoficzne, t. 1, Warszawa 1953, 190; tenże, In Joannis Evangelium tractatus 54, 3, ed. D.R. Willems, CCL 36, Turnholti 1954, 459-460, tłum. W. Szołdrski: Św. Augustyn, Homilie na Ewangelię i pierwszy list Jana, PSP 15/2, Warszawa 1977, 82; tenże, De consensu Evangelistarum II 21, 52, PL 34, 1102, tłum. J. Sulowski: Św. Augustyn, O zgodności Ewangelistów, PSP 50, 
Specjalnym przedmiotem wiary, spełniającym jednak powyższe kryteria, jest Bóg, który stworzył rzeczy ziemskie i niebiańskie oraz objawił się jako Trójca Święta, a szczególnie dostępny dla ludzkiego intelektu stał się poprzez tajemnicę wcielenia. On bowiem jest zupełnie nieuchwytny dla zmysłów i niepojęty dla rozumu ${ }^{10}$. Człowiek również w stosunku do Niego wierzy w rzeczy przeszłe (np. śmierć Chrystusa na krzyżu), teraźniejsze (Chrystus siedzący po prawicy Ojca) oraz przyszłe (Chrystus przyjdzie jako Sędzia) ${ }^{11}$, a także przyjmuje za prawdziwe starotestamentalne proroctwa, obietnice, cuda i słowa Chrystusa ${ }^{12}$.

Przedmiot wiary nie jest zatem zależny od arbitralnej decyzji podmiotu, choć wydaje się, że sam jej akt podlega jego woli, gdyż człowiek zawsze może w coś uwierzyć lub tę wiarę odrzucić. Jest to możliwe, ponieważ odnosi się ona do rzeczy, których umysł ludzki nie widzi lub zobaczyć nie może ze względu na ograniczoność własnej percepcji i które pozostają dla niego czymś niezrozumiałym ${ }^{13}$. Dlatego też biskup Hippony, powołując się na List do Hebrajczyków $(11,1)$, definiuje wiarę jako ,silne przeświadczenie o prawdzie rzeczy, których się nie widzi”"14 oraz ,przekonanie, które opiera się świadectwu

Warszawa 1989, 100; tenże, De Genesi ad litteram II 5, 9, PL 34, 1865, 266-267, thum. J. Sulowski: Św. Augustyn, Komentarz słowny do Księgi Rodzaju, w: Św. Augustyn Pisma egzegetyczne przeciw manichejczykom, PSP 25, Warszawa 1980, 135; tenże, Epistula 147, 4, PL 33, 598; tenże, De agone christiano 13, 15, PL 40, 299, thum. Budzik, s. 241; tenże, De civitate Dei XI 32, CCL 48, 351352, tłum. Kubicki, s. 405-406; M. Sołtysiak, Autorytet w czasach próby. Św. Augustyna koncepcja autorytetu, w: Księga Jubileuszowa z racji 50-lecia postugi kaptańskiej J.E. Ks. Bp. Dr. Adama Śmigielskiego, red. W. Kowalski - J. Orzeszyna - W. Skoczny, Kraków - Sosnowiec 2007, 227-228; J. Pelikan, Powstanie wspólnej tradycji (100- 600), thum. M. Hoffner, Kraków 2008, 313-314. Przyjęcie wiary opartej na autorytecie nie oznacza jednak zaprzestania poszukiwania Boga ani nie znosi odniesienia się wiary do Niego jako swego podstawowego przedmiotu. Ze względu na to oraz na rozległość tematu wpływu autorytetu na wiarę, zagadnienie to zostało jedynie w niniejszym artykule zasygnalizowane, ale nie będzie szerzej rozważane. Więcej na ten temat zob. M. Terka, Autorytet wiary w myśleniu religijnym św. Augustyna, „Veritati et Caritati” 1 (2013), 78-102.

${ }^{10}$ Por. Augustinus, De diversis quaestionibus octoginta tribus 54, CCL 44A, 93, thum. Radziejowska, s. 109.

${ }^{11}$ Por. tenże, Enchiridion ad Laurentium II 8, CCL 46, 51-52, tłum. Budzik, s. 81-82; tenże, De fide et operibus IX 14, ed. G. Ceriotti - L. Alici - A. Pieretti, NBA 6/2, Roma 1995, 716, tłum. W. Budzik: Św. Augustyn, Wiara i uczynki, w: Św. Augustyn, Pisma katechetyczne, s. 186; tenże, Sermo de symbolo ad catechumenos IV 11, ed. R. Vander Plaetse, CCL 46, 195, thum. W. Budzik: Św. Augustyn, Kazanie do katechumenów o wyznaniu wiary, w: Św. Augustyn, Pisma katechetyczne, s. 72.

${ }^{12}$ Por. tenże, De catechizandis rudibus 26, 50 - 27, 54, CCL 46, 173-177, thum. Budzik, s. 5559; tenże, De vera religione XXV 47, ed. I. Martin, CCL 32, Turnholti 1962, 216-217, thum. J. Ptaszyński: Św. Augustyn, O wierze prawdziwej, w: Św. Augustyn, Dialogi i pisma filozoficzne, t. IV, Warszawa 1954, 112.

${ }^{13}$ Por. tenże, De catechizandis rudibus 26, 50, CCL 46, 173-174, thum. Budzik, s. 56.

${ }^{14}$ Tenże, De Trinitate XIII 1, 3, NBA 4, 506, POK 25, 351; tenże, De catechizandis rudibus 25 , 47, CCL 46, 170-171, tłum. Budzik, s. 53; tenże, In Joannis evangelium tractatus 79, 1, CCL 36, 525-526, PSP 15/2, 170. Por. D. Zagórski, Commendavit nobis Dominus oves suas. Pasterska troska o wiernych w świetle ,, Sermones” św. Augustyna, Torun - Pelplin 2013, 363. 
zmysłów, a wierzy raczej poznaniu umysłowemu"15. Zakłada więc ona jakiś rodzaj niewiedzy, gdyż nie jest widzeniem prawdy, lecz raczej dążeniem do niej. Dlatego też Hippończyk naucza, że wiara jest tak bardzo odległa od prawdy, jak śmiertelność od wieczności. Prawda bowiem jest w swej istocie niezmienna, nieśmiertelna, czyli wieczna, a w ostateczności tożsama z samym Bogiem ${ }^{16}$. Tymczasem człowiek nie jest zdolny podczas swego życia na ziemi do jej pełnego poznania, gdyż ciagle zmagać się musi z brzemieniem grzechu i miłością doczesności, które go przytłaczają, sprowadzając do tego, co przyziemne. Przylgnąwszy zaś do rzeczy ziemskich, ludzki umysł odwraca się od światła prawdy i jej źródła, którym jest sam Bóg, stając się poprzez to coraz mniej zdolny do jej poznania. Wówczas jednak wiara w Boga skazana jest na oparcie się jedynie na własnych wyobrażeniach o Nim. Ów stan odwrócenia umysłu od światła nazywa Hippończyk „ciemnością” (tenebrae) $)^{17}$, zaś wiarę traktuje jako środek do jej przezwyciężenia ${ }^{18}$.

$\mathrm{Z}$ definicji tej wynika jednocześnie i to, że wiara rozumiana jako silne przeświadczenie o prawdzie, choć odnosi się do rzeczy niewidzialnych, to jednak umożliwia $\mathrm{w}$ jakimś stopniu poznanie czegoś $\mathrm{z}$ ich istoty. Jest ona bowiem początkiem drogi prowadzącej do prawdy i umożliwiającej jej zrozumienie ${ }^{19}$. Pewność płynąca z wiary zapoczątkowuje poznanie prawdy i rozbudza w człowieku pragnienie poszukiwania tego, co wieczne i niezmienne ${ }^{20}$. Niemniej jednak zawsze pozostaje ona jedynie początkiem drogi, a nigdy celem samym w sobie.

Chociaż zatem wiara jest drogą prowadzącą do spraw niewidzialnych i zmierzającą w swym ostatecznym celu do poznania Boga, to jednak ze względu na ludzki umysł pogrążony w ciemnościach doczesności, musi ona realizować się w tym, co ziemskie i odnosić się do rzeczy, które dokonały się w doczesności ${ }^{21}$. Biskup Hippony stwierdza zatem:

„Jasne więc, że to coś zupełnie różnego widzieć w sobie to, w co inny może uwierzyć na słowo, nie widząc tego; niż widzieć samą prawdę, którą inny tak samo może oglądać. Przedmiot pierwszego z wymienionych rodza-

${ }^{15}$ Augustinus, Soliloquia VII 14, ed. D. Gentili, NBA 3/1, Roma 1970, 404, thum. A. Świderkówna: Św. Augustyn, Solilokwia, w: Św. Augustyn, Dialogi i pisma filozoficzne, t. 2, s. 22.

${ }^{16}$ Por. tenże, De civitate Dei XI 32, CCL 48, 351-352, thum. Kubicki, s. 405.

${ }^{17}$ Por. tenże, De vera religione X 18, CCL 32, 199, tłum. Ptaszyński, s. 92; tenże, De Trinitate XIII 1, 2, NBA 4, 504, POK 25, 349; Zagórski, Commendavit nobis Dominus oves suas, s. 401; S. Isetta, Il llibro XI del „, De civitate Dei”, SEA 115 (2009) 52-53.

${ }_{18}$ Por. Augustinus, De Trinitate XIII 1, 2, NBA 4, 504, POK 25, 349. Zob. W. Kamczyk, Tota Paschalis Sollemnitas. Teologia i duszpasterstwo w kazaniach i homiliach św. Augustyna, red. W. Myszor, SACh SN 12, Katowice 2012, 235-237. Ludzki intelekt potrzebuje bowiem światła Bożego, by mógł poznać prawdę. Zob. R.H. Nash, Illuminazione divina, ADE, s. 818.

${ }^{19}$ Por. Augustinus, De Trinitate XV 27, 49, NBA 4, 712-714, POK 25, 456.

${ }^{20}$ Por. tamże IX 1, 1, NBA 4, 362-364, POK 25, 278.

${ }^{21}$ Por. tamże IV 18, 24, NBA 4, 214-216, POK 25, 198-199. Zob. Jaśkiewicz, Św. Augustynposzukiwanie Boga, s. 95. 
jów poznania podlega zmianom w czasie, podczas, gdy drugi jest wieczny i niezmienny"22.

Wiara byłaby więc rzeczywistością czasową, zanurzoną w doczesności, chociaż prowadzącą do tego, co wieczne. Wobec tego światło pochodzące od Boga i umożliwiające poznanie Go z konieczności musi posługiwać się środkami, które umożliwiają pogrążonemu w ciemnościach rozumowi rozpoznać w nich coś więcej niż tylko wymiar ziemski. Otwierając się na to światło i pozwalając się jemu prowadzić, ludzki umysł wchodzi na drogę, która nosi nazwę wiary.

Wydaje się zatem rzeczą słuszną uznać, że wiara zawiera w sobie jakąś cząstkę światła Bożego, które pozwala na poznanie i zrozumienie czegoś więcej niż jedynie to, co doczesne. Nie oznacza to jednak negacji jej doczesnego wymiaru, a nawet wręcz przeciwnie, staje się on stopniami, po których umysł może wznosić się ku Bogu. Św. Augustyn, porównując ciemności, w jakich został pogrążony ludzki umysł, do choroby, pisze o tym zjawisku w następujących słowach:

„Niezdolni do ogarnięcia rzeczy wiecznych, przytłoczeni brzemieniem zmaz grzechowych, które ściagnęła na nas miłość doczesności, wkorzeniona w nas razem z przekazaniem śmiertelnej natury - potrzebowaliśmy oczyszczenia. Ale oczyszczenie na sposób taki, byśmy mogli przez nie uzyskać jakieś dostosowanie i proporcjonalność wobec wieczności, mogło się dokonać jedynie za pośrednictwem rzeczy doczesnych, do których byliśmy przystosowani. Nie ulega wątpliwości, że zdrowie i choroba są sobie bardzo dalekie. Ale pośrednie pomiędzy nimi leki o tyle tylko przyczynią się do zdrowia, o ile dostosuje się je do choroby. Niepożyteczne rzeczy doczesne szkodzą chorym, natomiast stosowne i korzystne dopomagają w odzyskaniu zdrowia i uleczonych przeprowadzają do wieczności. Tak jak rozumna dusza ludzka ma oddać się kontemplacji rzeczy wiecznych, tak oczyszczać się powinna wierząc doczesnym”²3.

${ }^{22}$ Augustinus, De Trinitate IX 6, 9, NBA 4, 376: „Unde manifestum est, aliud unumquemque videre in se, quod sibi alius dicenti credat, non tamen videat; aliud autem in ipsa veritate quod alius quoque possit intueri; quorum alterum mutari per tempora, alterum incommutabili aeternitate consistere", POK 25, 284-285.

${ }^{23}$ Tamże IV 18, 24, NBA 4, 214: „Quia igitur ad aeterna capessenda idonei non eramus, sordesque peccatorum nos praegravabant temporalium rerum amore contractae, et de propagine mortalitatis tamquam naturaliter inolitae, purgandi eramus. Purgari autem ut contemperaremur aeternis, non nisi per temporalia possemus qualibus iam contemperati tenebamur. Sanitas enim a morbo plurimum distat, sed media curatio nisi morbo congruat non perducit ad sanitatem. Inutilia temporalia decipiunt aegrotos; utilia temporalia suscipiunt sanandos, et traiciunt ad aeterna sanatos. Mens autem rationalis sicut purgata contemplationem debet rebus aeternis, sic purganda temporalibus fidem", POK 25, 197-198; por. tenże, Enchiridion ad Laurentium XX 75, CCL 46, 90, thum. Budzik, s. 135; Zagórski, Commendavit nobis Dominus oves suas, s. 363; G. Bolis, L'idolatria in S. Agostino. Una perspectiva antrologica, Roma 2004, 246-251. 
Droga wiary prowadzi św. Augustyna od rzeczy ziemskich do kontemplacji prawd wiecznych i Stwórcy, którą Hippończyk uważa za zwieńczenie ( $f$ nis) wszelkich ludzkich wysiłków oraz utożsamia z osiagnięciem pełni szczęścia polegającego na życiu wiecznym z Bogiem. Kontemplacja ta, rozumiana jako widzenie Boga, jest zamknięciem poszukiwania Go, bo nie potrzeba szukać tego, co się już ogląda ${ }^{24}$. Wiara ukazana w tej perspektywie jawi się raczej jako nieustanne poszukiwanie boskości i wznoszenie się ku niej niż ujmowane statycznie przekonanie o jakiejś prawdzie. W związku z tym rzeczą konieczną wydaje się być prześledzenie owej wędrówki rozumu, gdyż prawda o funkcjonowaniu wiary odsłania się najpełniej dopiero na drodze, po której ona zmierza w stronę Boga.

\section{KU TEMU, CO NIEWIDZIALNE}

Istnienie Boga i Jego działanie w stosunku do człowieka odsłania się dopiero w perspektywie wiary. Dla niewierzącego pozostaje ono czymś zupełnie niezrozumiałym, a nawet wręcz absurdalnym. Hippończyk, komentując Prolog Ewangelii św. Jana, a szczególnie słowa traktujące o pojawieniu się w historii zbawienia Jana Chrzciciela posłanego przez Boga, by zaświadczyć o Boskiej Światłości, która przyszła na świat (por. J 1, 6-8), wskazuje na prosty fakt, że wszyscy ludzie są zdolni do tego, by wyobrazić sobie na podstawie znajomości ludzkiej natury oraz historii postać Jana i jego czyny. Niemniej jednak istotę jego postępowania, która wyraża się w wypełnieniu posłannictwa zleconego mu przez Boga, mogą uchwycić jedynie ludzie wierzący. Pozostali albo zupełnie nie rozumieją opisanej przez Ewangelistę sytuacji, albo też thumaczą ją sobie błędnie, bazując nie na prawdzie, lecz na własnych o niej wyobrażeniach ${ }^{25}$.

Wiara jest zatem siła, która pozwala człowiekowi dostrzec to, co niewidzialne dla innych ludzi, przejść od spraw ziemskich do niebiańskich i rozpoznać ślady wieczności w tym, co przemijalne i zmienne. Tego rodzaju znaki odnajduje św. Augustyn najpierw w świecie stworzonym przez Boga ${ }^{26}$, a potem w Piśmie Świętym. Na jego kartach bowiem autorzy natchnieni ukazują proces objawiania się Boga i rozpoznawania Boskości przez człowieka, a za środek do wzajemnej komunikacji służą rzeczy materialne i doczesne wydarzenia, które Bóg wykorzystuje do ukazania Siebie, w taki sposób, by ludzki umysł mógł je zrozumieć. Biblia mówiąc więc o Bogu, posługuje się wyrażeniami zaczerpniętymi ze świata zmysłowego i stosuje metafory i antropomorfizmy ${ }^{27}$. Prowadzi w ten sposób człowieka dostępnymi dla niego drogami

${ }^{24}$ Por. Augustinus, De Trinitate I 8, 17, NBA 4, 32-34, POK 25, 96-97. Zob. N.J. Torchia, Contemplazione e azione, ADE, s. 466-467.

${ }^{25}$ Por. Augustinus, De Trinitate XIII 1, 2-3, NBA 4, 502-506, POK 25, 349-350.

${ }^{26}$ Por. tamże VIII 7, 11, NBA 4, 350-352, POK 25, 272. Zob. Jaśkiewicz, Św. Augustyn - poszukiwanie Boga, s. 113-127.

${ }^{27}$ Analizy św. Augustyna dotyczące poszczególnych teofanii opisanych na kartach Pisma Świę- 
i przemawia do niego jak do dziecka, które ze względu na własną słabość i brak umiejętności posługiwania się rozumem, potrzebuje jeszcze mleka, a nie stałego pokarmu, przeznaczonego dla ludzi duchowych (por. 1Kor 3, 1-3) ${ }^{28}$.

1. Wiara w objawienie biblijne. Św. Augustyn zauważa bowiem, że już w Księdze Rodzaju ukazany jest Bóg, który występuje jakby w ludzkiej postaci i rozmawia ze stworzonym przez siebie człowiekiem, przechadza się po rajskim ogrodzie i szuka skrywającego się przed Nim Adama (por. Rdz 3, 8-10) ${ }^{29}$. Stwórca ukazuje się również Abrahamowi przyjmując jego gościnę pod dębami Mamre oraz korzystając ze schronienia w domu Lota (por. Rdz 18, $1-8 ; 19,10-29)^{30}$. Do tej logiki należy także objawienie dane Mojżeszowi za pośrednictwem gorejącego krzewu, gdzie Pan przedstawił się jako Bóg Abrahama, Izaaka i Jakuba (por. Wj 3, 1-6) 31 $^{1}$ oraz znaki słupa obłoku lub ognia, które prowadziły naród wybrany wychodzący z niewoli egipskiej (por. $\mathrm{Wj} 13$, 21-22) 32. Zgromadzony pod górą Synaj lud Izraela nie mógł oglądać Boga, a widział jedynie ogień, dym i błyskawice oraz odczuwał trzęsienie ziemi (por. Wj 19, 16-19; 20, 18-21) ${ }^{33}$. Nawet Mojżesz, o którym mówi Pismo Święte, że rozmawiał z Bogiem twarzą w twarz, jak zwykle człowiek rozmawia ze swym przyjacielem (por. Wj 33, 11), mimo wszystko nie oglądał oblicza Bożego, gdyż nie mógł on oczami ciała dostrzec duchowej istoty swego Stwórcy. Musiało to być raczej widzenie jakiegoś zjawiska dostępnego poznaniu zmysłowemu, a nie duchowe oglądanie Boga, gdyż - jak podkreśla Hippończyk sam Mojżesz prosił Pana, by pozwolił mu zobaczyć Jego oblicze (por. Wj 33, 18), lecz nie dostąił tej łaski, oglądając jedynie plecy przechodzącego Boga (posteriora Dei), gdyż niemożliwą rzeczą dla człowieka byłoby Go oglądać i pozostać przy życiu (por. Wj 33, 20-23) ${ }^{34}$.

tego mają na celu przede wszystkim określenie tego, która Osoba lub Osoby Boskie objawiają się w konkretnym wydarzeniu biblijnym. Te szczegółowe analizy naznaczone są jednak trudnościami interpretacyjnymi i dlatego nawet sam biskup Hippony nie upiera się przy własnych rozstrzygnięciach; por. De Trinitate II 9, 16, NBA 4, 92-94, POK 25, 132; tamże II 10, 18, NBA 4, 96, POK 25, 133; tamże II 18, 35, NBA 4, 124, POK 25, 149. Zagadnienie to w niczym nie wpływa jednak na kwestię rozpoznawania Boga poprzez wiarę, gdyż istotne jest dla niego jedynie to, że Bóg, rozumiany jako Trójca Święta, objawia się człowiekowi.

${ }^{28}$ Por. tenże, De diversis quaestionibus octoginta tribus 64, 6, CCL 44A, 142, tłum. Radziejowska, s. 171; tenże, De Trinitate I 1, 3, NBA 4, 8-10, POK 25, 82; tenże, Contra Faustum Manichaeum XII 46, PL 42, 279-280, thum. J. Sulowski: Św. Augustyn, Przeciw Faustusowi, ks. I-XXI, PSP 55, Warszawa 1991, 98; S. Tupaj, Miłosierdzie Boże i miłosierdzie chrześcijanina w świetle „Enarrationes in Psalmos” św. Augustyna, red. A. Uciecha, SACh SN 5, Katowice 2007, 128-130.

${ }^{29}$ Por. Augustinus, De Trinitate II 10, 17-18, NBA 4, 94-98, POK 25, 132-134.

${ }^{30}$ Por. tamże II 10, 19 - 12, 22, NBA 4, 98-104, POK 25, 134-138.

${ }^{31}$ Por. tamże II 13, 23, NBA 4, 104-106, POK 25, 138-139.

${ }^{32}$ Por. tamże II 14, 24, NBA 4, 106, POK 25, 139-140.

${ }^{33}$ Por. tamże II 15, 25, NBA 4, 108, POK 25, 140-141. Zob. N. Cipriani, Rivelazione, ADE, s. $1227-1228$.

${ }^{34}$ Por. Augustinus, De Trinitate II 17, 28-32, NBA 4, 112-120, POK 25, 143-147. To wydarze- 
Istota Boga pozostaje więc dla Mojżesza niepoznawalna i tajemnicza. W tym samym duchu interpretuje św. Augustyn również widzenia, jakie miewali starotestamentalni prorocy (np. Dn 7, 9-14) i podsumowuje biblijne teofanie następującymi słowami:

„Wiele takich widzeń zdarzyło się w owych czasach, w których się nie wymienia Ojca, Syna czy Ducha Świętego, a jednak towarzyszyły im pewne znaki, nie pozwalające twierdzić, że Bóg Ojciec nigdy nie ukazywał się patriarchom czy prorokom $\mathrm{w}$ jakiejś postrzegalnej dla zmysłów postaci. [...] Widzenia te odbywały się za pośrednictwem podległego zmianom stworzenia poddanego niezmiennemu Bogu i okazującego Boga nie w Jego istocie, ale w znakach i symbolach, w sposób dostosowany do potrzeb i okoliczności”35.

Podobne znaki i symbole, odsłaniające objawiającą się Boskość, dostrzega biskup Hippony również w wydarzeniach Nowego Testamentu. Taką rolę

nie Hippończyk interpretuje alegorycznie, przede wszystkim w kluczu chrystologicznym oraz eklezjologicznym. Dopatruje się tu bowiem prefiguracji Chrystusa, utożsamiając Jego „plecy”, które są dostrzegalne dla człowieka, z przyjętym przez Syna Bożego ciałem, zaś zakryte przed ludzkim wzrokiem oblicze identyfikuje z naturą Bożą. Odwołując się do świętych Apostołów Pawła (por. 1Kor 13, 12; 2Kor 5, 6-7) oraz Jana (1J 3, 2), św. Augustyn stwierdza, że dopóki jesteśmy pielgrzymami zdążającymi do swej ojczyzny w niebie, możemy oglądać Boga poprzez zasłonę Jego ciała, gdyż jedynie dzięki wierze, a nie widzeniu postępujemy, zaś dopiero w niebie ujrzymy Go takim, jakim jest. W czasie pielgrzymki człowiekowi dana jest więc tylko wiara we wcielenie, oraz w zmartwychwstanie Chrystusa, bowiem owym przejściem Boga, opisanym w Biblii, jest w pierwszym rzędzie Pascha, czyli przejście Chrystusa z tego świata do Ojca. Skoro zaś oglądanie objawiającego się Chrystusa możliwe jest na ziemi jedynie poprzez przyjęcie z wiarą Jego wcielenia i Paschy, to punktem, z którego można je widzieć najlepiej jest dla biskupa Hippony Kościół, zbudowany na fundamencie wiary, której symbolem jest skała. Sam Kościół jest bowiem ciałem Chrystusa, a wszyscy wierzący stanowią jego poszczególne członki złączone ze swoją Głową, wcielonym i uwielbionym Chrystusem; por. tenże, Enarrationes in Ps. 58(1), 2, ed. D.E. Dekkers - I. Fraipont, CCL 39, Turnholti 1956, 730, tłum. J. Sulowski, PSP 39, Warszawa 1986, 4; tamże 62, 2, CCL 39, 794-795, PSP 39, 74-75; J. Pałucki, Eklezjologia Ojców Kościoła, w: Kościół w czasach Jana Pawła II, red. M. - Rusecki - K. Kaucha - J. Mastej, Lublin 2005, 99-112. Patrzący na Chrystusa ze skały Kościoła chrześcijanie są umocnieni mocą samego Boga, a ich oglądanie Go jest dla nich zbawienne. Z kolei Mojżesz jest dla biskupa Hippony prefiguracją tych spośród narodu żydowskiego, którzy nie rozpoznali w Jezusie z Nazaretu swego Boga, ale po Jego zmartwychwstaniu, czyli po Jego przejściu, zobaczyli Go jakby od tyłu, słysząc głos Piotra nawołujący ich do nawrócenia i uznania w Ukrzyżowanym swego Zbawcy. Dopiero wówczas, przejęci żalem i z sercem skruszonym wyznali wiarę w Chrystusa (por. Augustinus, Enarrationes in Ps. 138, 8, CCL 40, 1996-1997, PSP 42 , 180), zob. M. Terka, Objawienie Logosu w nauczaniu św. Augustyna, w: Wczesne chrześcijaństwo a religie, red. I.S. Ledwoń - M. Szram, Lublin 2012, 511-512.

${ }^{35}$ Augustinus, De Trinitate II 17, 32, NBA 4, 120: „Multa enim talia visa facta sunt illis temporibus non evidenter nominato et designato in eis vel Patre vel Filio vel Spiritu Sancto, sed tamen per quasdam valde probabiles significationes nonnullis indiciis exsistentibus ut nimis temerarium sit dicere Deum Patrem numquam Patribus aut Prophetis per aliquas visibiles formas apparuisse. [...] Visiones autem illae per creaturam commutabilem Deo incommutabili subditam factae sunt, non proprie sicuti est, sed significative sicut pro rerum causis et temporibus oportuit ostendentes Deum", POK 25, 146-147. 
pełnią zdziałane przez Chrystusa cuda ${ }^{36}$, znaki towarzyszące zesłaniu Ducha Świętego ${ }^{37}$. Miały one - zdaniem św. Augustyna - poprzez ukazanie oczom niezwykłego widoku, wzruszyć serce człowieka i zwrócić je w stronę przychodzącego Boga. Stworzenie, którym posługuje się Bóg dla komunikacji z człowiekiem, pełni więc funkcję symbolu odsyłającego poza siebie, ku temu, co niezmienne i wieczne, a jednocześnie skrywającego w sobie wielką Tajemnicę $^{38}$. Znaleźć ją tam może jednak tylko zdrowa wiara (sana fides) ${ }^{39}$.

Znaki te, odsłaniając prawdę o Bogu, utrzymują jednocześnie Jego tajemnicę, gdyż są jedynie doczesnymi środkami służącymi wyrażenia tego, co wieczne. Dlatego też droga wiary jest związana z niebezpieczeństwem skupienia się wyłącznie na zmysłowym doświadczeniu, które nie tylko nie prowadzi do odnalezienia Boga, lecz utwierdza ludzi w błędnych wyobrażeniach o Nim. Stąd biskup Hippony podkreśla fakt, że niektórzy przenoszą wiedzę o doczesności, uzyskaną własnym wysiłkiem intelektualnym, na rzeczywistość natury duchowej, inni z kolei wyobrażają sobie Boga przeprowadzając analogię pomiędzy Nim a własnym umysłem. Wszyscy oni wytwarzają sobie jednak fałszywe pojęcie o Bogu i nie tylko Go nie odnajdują, lecz jeszcze bardziej pogrążają się w ciemnościach błędu bałwochwalstwa ${ }^{40}$.

Wiara okazuje się być potrzebną szczególnie przy specjalnym spotkaniu tego, co Boskie ze śmiertelną ludzką naturą, jakie dokonało się w tajemnicy wcielenia Syna Bożego. Hippończyk w taki oto sposób ujmuje konieczność i rolę wiary w tym wydarzeniu:

„Żeby jednak ta wiara śmiertelnego życia nie była niezgodna z prawdą życia wiecznego, sama Prawda współwieczna Ojcu narodziła się na ziemi (Ps 85, 12), gdy Syn Boży zstąpił na ziemię w taki sposób, iż stał się Synem Człowieczym, iż przyjmując naszą śmiertelność nie wyzbył się przez to swojej wieczności. Wtedy sam osobiście stał się przedmiotem naszej wiary, która doprowadzi nas do Jego Prawdy. Tak bowiem rzeczy powstające w czasie mają się do wieczności, jak się ma wiara do prawdy. Więc trzeba było oczyścić nas, żeby mógł narodzić się dla nas ten, który zarazem pozostał wiecznym i żeby nie przedstawiał się On dla nas inaczej w wierze i inaczej w prawdzie"41.

${ }^{36}$ Por. tamże IV 19, 25, NBA 4, 216-218, POK 25, 199-200; tamże I 6, 11, NBA 4, 20-22, POK 25, 90.

${ }^{37}$ Por. tamże II 5, 10 - 6, 11, NBA 4, 82-86, POK 25, 125-128.

${ }^{38}$ Por. tamże.

${ }^{39}$ Por. tamże II 17, 32, NBA 4, 120, POK 25, 147.

${ }^{40}$ Por. tamże I 1, 1, NBA 4, 6, POK 25, 79-80; tenże, De symbolo ad catechumenos IV 11, CCL 46, 195, tłum. Budzik, s. 72; Bolis, L'idolatria in S. Agostino, s. 233-246.

${ }^{41}$ Augustinus, De Trinitate IV 18, 24, NBA 4, 214-215: ,[...] ne fides mortalis vitae dissonaret a veritate aeternae vitae, ipsa Veritas Patri coaeterna «de terra orta est» (Ps 85, 12), cum Filius Dei sic venit ut fieret filius hominis, et ipse in se exciperet fidem nostram, qua nos perduceret ad Veritatem suam, qui sic suscepit mortalitatem nostram, ut non amitteret aeternitatem suam. "Quantum 
Pomimo tego, że wcielenie Słowa Bożego jest najsilniejszym strumieniem światła Bożego wlanym w ludzki świat i pozwalającym dostrzec w nim obecność Boga, to jednak ono również stanowi wyzwanie dla ludzkiego umysłu. Ciało bowiem, mówiąc o niepojętej dotychczas dla człowieka bliskości Boga, ciągle ją zakrywa domagając się wejścia na drogę wiary. $Z$ tego powodu wielu członków narodu żydowskiego nie rozpoznało w Jezusie z Nazaretu obiecanego Mesjasza. Symbolem tego niezrozumienia, a w konsekwencji niewiary, jest odrzucenie Chrystusa wyrażone w Jego krzyżu ${ }^{42}$.

Istota wiary ujętej jako poszukiwanie Boga w zakrywająco-odsłaniających ją znakach wyraża się - zdaniem św. Augustyna - w symbolach, jakimi są dla niego postaci Marii Magdaleny i Tomasza Apostoła. Gdy bowiem wczesnym rankiem, po szabacie, Maria Magdalena udała się do grobu Chrystusa, by namaścić Jego ciało i zastała pusty grób oraz aniołów oznajmujących jej, że Jezus żyje, nie rozpoznała Go mówiącego do niej myśląc, że jest to ogrodnik (por. J 20,11-18). Biskup Hippony podkreśla, że w ewangelicznym opisie tego wydarzenia Maria, usłyszawszy głos Jezusa, odwróciła się dwukrotnie. Najpierw błędnie zidentyfikowała swego rozmówcę, gdyż obróciła się jedynie ciałem (conversa corpore), gdy zaś usłyszała swoje imię wypowiadane przez Nieznajomego, obróciwszy się sercem (corde conversa), poznała w Nim swego Pana. Na drogę wiary wprowadził ją jednak sam Chrystus, wówczas, gdy nie pozwolił się dotknąć, dotąd, dopóki nie wstąpi do swego Ojca. Hippończyk interpretuję tę sytuację następująco:

„[...] gdy jej powiedziano: «Nie dotykaj mnie», to jest nie wierz we mnie tak, jak dotąd mnie pojmowałaś, nie chciej swego uczucia do tego rozciagać, czym stałem się dla ciebie, bez (równoczesnego) przejścia do Tego, przez którego się stałaś. Czyż bowiem nie cieleśnie jeszcze w Niego wierzyła, którego jako człowieka opłakiwała? «Jeszcze bowiem - mówi - nie wstąiłem do mego Ojca», tam mnie dotkniesz, kiedy uwierzysz, że nie jestem Bogiem nierównym Ojcu" ${ }^{\text {"43 }}$.

Wiara obudzona w Marii Magdalenie pozwala jej zatem dostrzec kogoś więcej niż tylko ogrodnika czy też Jezusa, którego do tej pory znała. Podobna

enim ad id quod ortum est aeternitas valet, tantum ad fidem veritas» (Plato, Timaeus 29c). Ita ergo nos purgari oportebat, ut ille nobis fieret ortus qui maneret aeternus, ne alter nobis esset in fide, alter in veritate”, POK 25, 198. Por. tenże, De civitate Dei XI 2, CCL 48, 322, thum. Kubicki, s. 405.

${ }^{42}$ Por. tenże, Enarrationes in Ps. 138, 8, CCL 40, 1996-1997, PSP 42, 180; tamże 76, 22, CCL 39, 1065, PSP 39, 370-371; tamże 33(1), 7, CCL 38, 278, PSP 37, 328; tamże 55, 2, CCL 39, 677 678, PSP 38, 347; Terka, Objawienie Logosu, s. 512-515.

${ }^{43}$ Augustinus, In Joannis evangelium tractatus 121, 3, CCL 36, 666: „[...] cum ei dicitur: «Noli me tangere»: id est: Noli in me sic credere, quemadmodum adhuc sapis; noli tuum sensum huc usque pertendere quod pro te factus sum, nec transire ad illud per quod facta es. Quomodo enim non carnaliter adhuc in eum credebat, quem sicut hominem flebat? «Nondum enim ascendi», inquit, «ad Patrem meum»: ibi me tanges, quando me credideris Patri non imparem Deum", PSP 15/2, Warszawa 1977, 350-351. Por. Kamczyk, Tota Paschalis Sollemnitas, s. 238-239. 
sytuacja zachodzi również w przypadku drugiego adresata chrystofanii, który nie uwierzył słowom swoich towarzyszy wędrówek z Jezusem, ale chciał sam przekonać się o prawdziwości ich świadectwa. Gdy zatem Zmartwychwstały przyszedł specjalnie do swego niedowierzającego ucznia i pozwolił się dotknąć ukazując mu swe rany, Tomasz, chociaż widział ludzkie ciało, wyznał w nim Boga, którego ani zobaczyć, ani dotknąć przecież nie mógł (por. J 20, 24-29)44.

Wiara wydaje się więc być swego rodzaju pragnieniem dotknięcia tego, czego dotknąć nie można, bo wymyka się ludzkim zmysłom i odkrywaniem obecności Boga. Skoro zaś zmysłowe znaki, za którymi ukrywa się Bóstwo, bywają nie tylko środkiem wzajemnej komunikacji, lecz także przeszkodą w rozpoznaniu i poszukiwaniu Boga, to wydaje się, że w procesie rozwoju wiary, muszą one odgrywać coraz mniejszą rolę. Biskup Hippony w komentarzu do opisanego wyżej spotkania Marii Magdaleny z Chrystusem zmartwychwstałym podkreśla bowiem, że Jezus zabronił jej dotknąć się, gdyż uważał, że dotknięcie jest uwieńczeniem poznania (finis notionis), a nie chciał, by Jego uczniowie zatrzymywali się jedynie na tym, co widoczne dla oczu. Odejście Chrystusa do Ojca miało zatem jeszcze wyraźniej niż zmartwychwstanie ukazać Jego Bóstwo i równość z Ojcem. Dopiero rozpoznanie w Jezusie prawdziwego i odwiecznego Boga jest celem każdej autentycznej wiary. Patrząc z tego punktu widzenia - zauważa Hippończyk - konieczne było wniebowstąpienie Chrystusa, czyli Jego odejście do Ojca, by „postać sługi”, którą przyjął dla zbawienia człowieka, nie zakrywała Jego równości z Ojcem, a uczniowie nie zatrzymywali się wyłącznie na tym, co widzą oczyma ciała ${ }^{45}$.

Znaki te nie moga jednak zostać zupełnie pozbawione znaczenia, gdyż wówczas wiara przestałaby być sobą, a przemieniłaby się w widzenie Boga, co możliwe jest dopiero w wieczności. Niemniej jednak w miarę wzrostu wiary tracą one charakter spektakularnych wydarzeń oddziałujących na zmysły człowieka, a coraz bardziej przemawiają do jego umysłu, przybierając postać duchową. Rozum podążający drogą wiary w poszukiwaniu Boga musi zatem podejmować wysiłek odrywania się od świata zmysłowego, a kierując się w stronę tego, co duchowe, odnajdywać to przede wszystkim we własnym wnętrzu. Wiara prowadzi zatem od świata do ludzkiej duszy, a znaki odsłaniające Boskość, chociaż stają się coraz subtelniejsze i trudniejsze do odkrycia, to jednak coraz mniej przesłaniają Boga. Skoro bowiem Bóg jest duchem, to znaleźć Go można jedynie poprzez to, co duchowe.

2. Wiara - widzenie w zwierciadle. Chociaż wiara jest rzeczywistością doczesna, a ze względu na jej intencjonalny charakter kieruje się ku przedmiotowi, który może należeć do świata zewnętrznego, to jednak akt wiary zawsze

${ }^{44}$ Por. Augustinus, In Joannis evangelium tractatus 121, 5, CCL 36, 667-668, PSP 15/2, $352-$ 353; Zagórski, Commendavit nobis Dominus oves suas, s. 366.

${ }^{45}$ Por. Augustinus, De Trinitate I 9, 18, NBA 4, 38, POK 25, 99. Zob. Zagórski, Commendavit nobis Dominus oves suas, s. 366. 
pozostaje dla człowieka czymś najbardziej wewnętrznym. Stąd też św. Augustyn podkreśla, że jest ona sprawą serca, a nie ciała ${ }^{46}$.

W poszukiwaniu Boga, napełniony wiara umysł ludzki, musi zatem nie tylko oderwać się od zmysłowego sposobu myślenia, lecz także zwrócić się w stronę rzeczywistości, którą biskup Hippony określa mianem człowieka wewnętrznego (homo interior), by odkryć siebie jako duszę zwróconą w stronę tego, co wieczne i niezmienne oraz by dzięki temu móc w kontemplacji rzeczy duchowych odkryć obraz Boga ${ }^{47}$. Wiara nie pozwala zatem rozumowi na zatrzymanie się przy analizie swoich własnych myśli i przeżyć, lecz zawsze odsyła do tego, co jest wyższe i lepsze od najlepszej nawet części duszy. Dzięki temu, umysłowi ludzkiemu ukazuje się to, co naprawdę w przedmiocie wiary jest istotne, zaś sprawy związane ze światem zmysłowym zostają zepchnięte na dalszy plan. Dla niej nie jest bowiem ważny fizyczny wygląd Chrystusa, nie zatrzymuje się ona na badaniu rysów twarzy Maryi czy też Apostołów, ani nie skupia swej uwagi na zewnętrznych przejawach cudów czynionych przez Jezusa. Ważne jest jedynie to, by wierzyć niewzruszonym sercem (inconcussum cor), że Bóg stał się człowiekiem i przyjął ciało z Maryi Dziewicy, że umarł i zmartwychwstał, by uwolnić ludzi z więzów grzechu. Odwrócony od zmysłowego świata umysł lepiej potrafi rozpoznać w cudach Jezusa przejawy Boskiej mocy oraz działanie łaski Bożej w życiu i czynach posłanych do głoszenia Ewangelii Apostołów. Pozostałe zaś rzeczy - jak podkreśla Hippończyk - każdy chrześcijanin może wyobrażać sobie zupełnie dowolnie, bez żadnej szkody dla prawdy wiary, choćby nawet te wyobrażenia były zupełnie błędne. Byłoby jednak czymś niezwykle szkodliwym dla wiary poddawanie w wątpliwość tego, co dla niej istotne ${ }^{48}$.

Umysł ludzki, oczyściwszy się ze zmysłowego uwikłania wyobraźni oraz pozwalając prowadzić się wierze, zwraca się ku kontemplacji prawd wiecznych, poszukując w nich śladów Niewidzialnego. Człowiek pragnie bowiem widzieć siłami rozumu to, w co uwierzy ${ }^{49}$. Analizując zatem ludzką duszę, biskup Hippony rozpoznaje, że została ona ukształtowana na obraz i podobieństwo Boga. Obraz ten, zawarty w najwyższej, rozumnej części duszy, sprawia, że człowiek, chociaż zmienny, a przez to ciagle zagrożony zniekształceniem swego podobieństwa do Boga poprzez grzech, jest jednak nastawiony na najwyższą naturę (summa natura) i posiada zdolność uczestnictwa w niej ${ }^{50}$. Dzię-

${ }^{46}$ Por. Augustinus, De civitate Dei XXII 29, CCL 48, 860, thum. Kubicki, s. 961-962; tenże, De Trinitate XIII 2, 5, NBA 4, 508-510, POK 25, 352. Zob. I. Bochet, Cuore, ADE, s. 527-531; T. Špidlik - I. Gargano - V. Grossi, Historia duchowości, t. 3: Duchowość Ojców Kościoła, thum. K. Stopa, Kraków 2004, 361-363; Jaśkiewicz, Św. Augustyn - poszukiwanie Boga, s. 89-90.

${ }^{47}$ Por. Augustinus, De Trinitate XII 1, 1 - 4, 4, NBA 4, 464-466, POK 25, 329-331. Zob. Zagórski, Commendavit nobis Dominus oves suas, s. 388-394; Cipriani, Rivelazione, ADE, s. 1227-1228.

${ }^{48}$ Por. Augustinus, De Trinitate VIII 4, 7 - 5, 7, NBA 4, 336-340, POK 25, 264-266.

${ }^{49}$ Por. tamże XV 28, 51, NBA 4, 718, POK 25, 458.

${ }^{50}$ Por. tamże XIV 4, 6, NBA 4, 570-572, POK 25, 384-385; tamże XIV 8, 11, NBA 4, 582, POK 25, 390. Zob. A. Eckmann, Przebóstwienie człowieka w pismach wczesnochrześcijańskich, Lublin 
ki temu właśnie człowiek potrafi przedkładać rozumność nad nierozumność, sprawiedliwość nad niesprawiedliwość, dobro nad zło, piękno nad brzydotę, szczęście niezmienne ponad to, co nieszczęśliwe i przemijające ${ }^{51}$.

Wpatrując się więc w obraz Boży wyciśnięty na ludzkiej duszy, może człowiek odnaleźć i poznać najwyższą i wieczną Naturę, a tym samym głębiej zrozumieć samego siebie ${ }^{52}$. Św. Augustyn podkreśla jednak, że obraz ten nie jest jednak Bogiem, a tylko Jego odbiciem i dlatego również on pełni funkcję znaku, który objawiając Boga, zakrywa Go jednocześnie mrokiem tajemnicy domagającej się wiary ${ }^{53}$. Wyjaśniając to zjawisko, przywołuje on słowa św. Pawła Apostoła, który stwierdził, że w obecnym czasie widzimy Boga jakby w zwierciadle (speculum) i w zagadce (aenigma), natomiast ,twarzą w twarz" zobaczymy Go dopiero w wieczności (por. 1Kor 13, 12). Owo zwierciadło jest dla Hippończyka właśnie obrazem, w którym usiłuje on dostrzec ślady Boga, zaś przez zagadkę rozumie on gatunek alegorii, ale zakrytej i niejasnej, która wskazuje na niewyraźne podobieństwo umożliwiające poznanie Boga wyłącznie w niewielkim i ograniczonym zakresie ${ }^{54}$.

Obraz nie może więc zatrzymywać uwagi na sobie, lecz wskazuje na coś więcej, tj. na rzeczywistość, której jest obrazem. Człowiek zatem, analizując własną duszę i dostrzegając wpisane w nią skierowanie ku Bogu, musi odnieść to, co zobaczył w sobie do swego Wzoru, a patrząc w zwierciadło domyślać się (conicere) ${ }^{55}$ Tego, którego zobaczyć jeszcze nie może, a Który się w nim odbija. Św. Augustyn podkreśla bowiem - zgodnie ze słowami Apostoła - że

2003, 137-143; Bochet, Cuore, ADE, s. 528; L.F. Pizzolato, Il libro XIII del „,civitate Dei”, SEA 115 (2009) 100. W duszy rozumnej wyróżnia Hippończyk triadę składającą się z duszy, poznania, poprzez które zna ona siebie oraz miłość, dzięki której może kochać siebie i swoje poznanie. Inna triada z kolei składa się z pamięci, inteligencji i woli (por. De Trinitate XV 3, 5, NBA 4, 622, POK 25, 411; Isetta, Il llibro XI del „De civitate Dei”, s. 45-49). Szczegółowe analizy tego zagadnienia nie zmieniają jednak niczego w rozjaśnieniu zagadnienia wiary i widzenia Boga. Dlatego też problem istnienia i funkcjonowania różnych triad w człowieku i ich odniesienie do Boga zostaną pominięte $\mathrm{w}$ dalszych rozważaniach. Wyjątkiem będzie jedynie triada wiary, która ściśle należy do podjętego w niniejszym artykule tematu.

${ }^{51}$ Por. Augustinus, De Trinitate XV 4, 6, NBA 4,624-646, POK 25, 412. Zob. W. Hankey, Mente, ADE, s. 939-940.

${ }^{52}$ Por. Augustinus, De Trinitate XV 5, 7, NBA 4, 626-628, POK 25, 413. Zob. Bochet, Cuore, ADE, s. 528.

${ }^{53}$ Por. Augustinus, De Trinitate XV 6, 10, NBA 4, 632-634, POK 25, 416.

${ }^{54}$ Por. tamże XV 8, 14 - 9, 16, NBA 4, 640-646, POK 25, 420-423; tenże, Enchiridion ad Laurentium XVI 63, CCL 46, 83, thum. Budzik, s. 125-126; tenże, De diversis quaestionibus octoginta tribus 74, CCL 44A, 213, thum. Radziejowska, s. 261. Zob. R.J. Desimone, Introduzione alla teologia del Dio Uno e Trio. Da Tertuliano ad Agostino, „Sussidi Patristici” 9 (1995) 114-116.

${ }^{55}$ M. Stokowska przełożyła słowo: conicio, -ere, -ieci, -iectum jako „wyczuwać”. Termin ten posiada jednak m.in. następujące znaczenie: „przypuszczać, wnioskować, domyślać się, tłumaczyć sny, znaki wróżebne" (Plezia I 686). Wydaje się, że powyższa gama semantyczna oddaje lepiej myśl Augustyna, sugerując, że chodzi tu o zaangażowanie rozumu w odczytywanie obrazu Boga, a nie emocjonalne, czy też intuicyjne poznawanie, na które bardziej otwiera termin „wyczuwać”. 
w obecnym czasie nie widzimy jedynie zwierciadła, lecz widzimy w zwierciadle, w sposób niewyraźny i enigmatyczny.

Do tego jednak, by cokolwiek zobaczyć w zwierciadle, czyli, by znów nie zatrzymać się na tym, co widzialne, choćby tym razem miało ono charakter duchowy, czyli by poszukiwanie Boga w duszy nie przerodziło się w zwykłą analizę psychologiczna, niezbędna jest wiara, poprzez którą serce człowieka oczyszcza się i przygotowuje do oglądania Boga "twarzą w twarz" ${ }^{56}$. Ona bowiem pełni funkcję podstawy (fundamentum) umożliwiającej wznoszenie się ku rozumieniu, czyli widzeniu myślą jej przedmiotu, którego oglądanie dane będzie dopiero w wieczności. Wiara pełni więc rolę przewodnika rozumu na drodze myślenia o Bogu i poszukiwania Go; przewodnika koniecznego z tego względu, że nie pozwalającego na spoczynek w tym, co Bogiem nie jest i skłaniającego do ciagłego wpatrywania się w zwierciadło, by w obrazie zobaczyć Jego odbicie ${ }^{57}$.

Wydaje się zatem, że w myśleniu św. Augustyna o wierze zawiera się pewne napięcie, które determinuje określenie jej jako właśnie poszukiwanie tego, co niewidzialne. Zawiera się $\mathrm{w}$ niej bowiem pragnienie uchwycenia Niewidzialnego, które nie zadowala się kolejnymi, choćby coraz bardziej subtelnymi, zmysłowymi i duchowymi znakami. Ową wewnętrzną dynamikę wiary ujmuje biskup Hippony w następujących słowach:

„Jeżeli szukając Go, można Go znaleźć, to dlaczego powiedziano: «Szukajcie zawsze Jego oblicza»? (Ps 105, 4). A może znalazłszy Go, trzeba Go jeszcze szukać? Istotnie, w taki bowiem sposób szuka się rzeczy nieuchwytnych. I nie należy sądzić, że się nic nie znalazło, jeśli się odkryło, jak dalece nieuchwytne jest to, czego się szukało. Więc po co Go szukać, jeśli się pojęło, że jest nieuchwytny? Po to właśnie, żeby poszukiwania nie przerwać. Jak długo coraz bardziej zgłębia się nieuchwytne, tym lepszym staje się szukający tak wielkiego Dobra. Bo czyż nie szuka się, żeby Go znaleźć, a znajduje się, aby Go jeszcze szukać. Szuka się Go, aby Go znaleźć z tym większą radością, a znajduje się, aby Go jeszcze tym gorliwiej szukać. [...] Wiara szuka, rozum odkrywa. [...] Po to człowiek ma rozum, żeby szukać Boga" ${ }^{58}$.

${ }^{56}$ Por. Augustinus, Contra Felicem Manichaeum II 13, PL 42, 544-545, tłum. J. Sulowski: Św. Augustyn, Przeciw Feliksowi, PSP 54, Warszawa 1990, 241; tenże, De Trinitate XV 23, 44-24, 44, NBA 4, 698-702, POK 25, 449-450; tenże, Enchiridion ad Laurentium XX 75, CCL 46, 90, thum. Budzik, s. 135. Zob. Desimone, Introduzione alla teologia del Dio Uno e Trio, s. 89.

${ }^{57}$ Por. Augustinus, De Trinitate XV 27, 49, NBA 4, 712-714, POK 25, 456; tenże, Enchiridion ad Laurentium XVIII 68 CCL 46, 86-87, tłum. Budzik, s. 130; Zagórski, Commendavit nobis Dominus oves suas, s. 394-396; Jaśkiewicz, Św. Augustyn - poszukiwanie Boga, s. 95.

${ }^{58}$ Augustinus, De Trinitate XV 2, 2, NBA 4, 616-618: „Si ergo quaesitus inveniri potest, cur dictum est: «Quaerite faciem eius semper»? (Ps 104, 4) An et inventus forte quaerendus est? Sic enim sunt incomprehensibilia requirenda, ne se existimet nihil invenisse, qui quam sit incomprehensibile quod quaerebat, potuerit invenire. Cur ergo sic quaerit, si incomprehensibile comprehendit esse quod quaerit, nisi quia cessandum non est, quamdiu in ipsa incomprehensibilium rerum inquisitione proficitur, et melior meliorque fit quaerens tam magnum bonum, quod et inveniendum 
Skoro wiara wyraża się ciągłym wyglądaniem tego, co niewidzialne i niezmienne, w uporczywym wpatrywaniu się w zwierciadło, by szukać rzeczywistości znajdującej się poza i ponad nim, to oznacza to, iż nie tylko nieustannie wykracza ona poza świat widzialny, lecz również nie można jej zamknąć wyłącznie w sferze świadomości człowieka. Obecne w niej pragnienie dotknięcia samego Boga sprawia - jak się wydaje - że nie można jej pojmować wyłącznie jako pewnego rodzaju stanu świadomości, lecz musi ona być czymś, co wymaga zaangażowania w proces poszukiwania Boga nie tylko sił intelektualnych, ale wszystkich wymiarów człowieczeństwa.

Źródło owego pragnienia, które skłania człowieka do niestrudzonego kierowania się w stronę objawiająco-skrywającego się Boga, widzi Hippończyk W wewnętrznej strukturze aktu wiary. Rzeczą konieczną jest zatem spojrzenie na to zjawisko od wnętrza, by odsłonić działające w nim mechanizmy i zrozumieć dynamikę wiary.

\section{DYNAMIKA WIARY}

Wewnętrzną strukturę aktu wiary opisuje biskup Hippony za pomocą odkrytej przez siebie i funkcjonującej w jej wnętrzu triady, która wyraża się w pamięci (memoria), widzeniu (contuitio) i miłości (dilectio) ${ }^{59}$. Umysł ludzki dostrzega najpierw sam akt wiary, gdy człowiek poznaje siebie jako wierzącego. Widząc swoją wiarę, dzięki której wierzy, zachowuje ją, ogląda i zwraca się do niej z miłością ${ }^{60}$. Triada wiary nie jest jednak obrazem Boga ${ }^{61}$ i dlatego nie może skupić się na oglądaniu samej siebie, lecz powinna zwracać się do tego, w co wierzy, czyli do swego przedmiotu.

Skoro zatem wiara kieruje się ku temu, czego nie widzi, to zawarta w niej triada musi wyrażać i wyjaśniać również to dążenie. Św. Augustyn zauważa bowiem, że umiejscawia się ona najpierw w pamięci pobudzając myśl człowieka wierzącego, by zachowywał to wszystko, co poznał o Bogu ${ }^{62}$. Dzięki temu

quaeritur, et quaerendum invenitur? Nam et quaeritur ut inveniatur dulcius, et invenitur ut quaeratur avidius. [...] Fides quaerit, intellectus invenit [...]. Ad hoc ergo debet homo esse intellegens, ut requirat Deum”, POK 25, 408. W tym kontekście J.M. Szymusiak (Wstęp, w: św. Augustyn, O Trójcy Świętej, POK 25, 31) zauważa: „Ostatnim słowem tego poszukiwania będzie stwierdzenie tajemnicy: nie ma bowiem bardziej autentycznego poznania Boga niż odkrycie Jego nieuchwytności. Ale ta nieuchwytność nie przekreśla poszukiwani; podnieca je tylko. Takie bowiem jest życie wiary - zawarte w stosunku do poznania i miłości: miłość dąży do poznania, a poznania wzmacnia miłość". Por. Jaśkiewicz, Św. Augustyn - poszukiwanie Boga, s. 110.

${ }^{59}$ Por. Augustinus, De Trinitate XIV 2, 4, NBA 4, 566, POK 25, 382. Zob. Desimone, Introduzione alla teologia del Dio Uno e Trio, s. 109-112; Jaśkiewicz, Św. Augustyn - poszukiwanie Boga, s. 136-140.

${ }^{60}$ Por. Augustinus, De Trinitate XIV 2, 4 - 3, 5, NBA 4, 566-570, POK 25, 382-383.

${ }^{61}$ Por. tamże XIV 2, 4, NBA 4, 566, POK 25, 381.

${ }^{62}$ Por. tamże XIV 3, 5, NBA 4, 568, POK 25, 383. 
zyskuje ona pewną treść i staje się pamięcią o słowach Bożych, wydarzeniach, w których się On objawiał, o Jego przykazaniach i obietnicach ${ }^{63}$.

Poszukiwanie niewidzialnego Boga wymaga jednak również ciąłego przypominania sobie o Nim. Polega ono w głównej mierze na oglądaniu w myśli (kontemplacji) tego, co jest przedmiotem wiary zawartym w pamięci ${ }^{64}$. Wydaje się, że te człony triady wiary podkreślają jej aspekt poznawczy i zawierają jak zauważa biskup Hippony - „wszystkie wiadomości w duszy wierzącego wywodzące się z wiary" ${ }^{\prime 65}$. Dzięki temu wiara posiada w sobie zdolność rozpoznawania znaków, poprzez które przemawia $\mathrm{w}$ doczesności wieczny i niezmienny Bóg. Ponieważ jednak nie chce ona poprzestać na tym, co widzialne, to oznacza to, że jest ona skierowana nie tylko na zdobycie jakichś wiadomości o Bogu, lecz przede wszystkim chce poznać Jego samego. W jej istocie zawarte jest zatem dążenie do wiecznej i niezmiennej prawdy, a nie do tymczasowych informacji, gdyż posiadanie ich nie oznacza jeszcze, że ten, kto wie cokolwiek o objawieniu Bożym, wcale nie musi być człowiekiem żyjącym według ducha. Hippończyk zauważa bowiem, że są ludzie, którzy mogą przechowywać w pamięci naukę wiary i przypominać ją sobie po to, by ją fałszywie oceniać lub nawet zwalczać. Dlatego też do tego, by wiara mogła być w pełni sobą, konieczny jest jeszcze trzeci człon jej triady, czyli miłość. Dzięki niej bowiem człowiek wierzący może kochać zawarte w pamięci i przypominane w oglądaniu prawdy wiary, a zwracając ku nim swoją wolę, przylgnąć do tego, w co uwierzył i co ukocha ${ }^{66}$. Dopiero w tak ujętej triadzie wiara może być zachowywana, widziana i miłowana, a poprzez to być wiarą żywą i trwałą ${ }^{67}$.

Biskup Hippony podkreśla jednak, że tego rodzaju miłość działa w wierze i przez wiare, kochając po prostu to, w co wierzy, a nie to, co zna, gdyż przedmiotu, ku któremu się kieruje, zobaczyć nie może. Z tego względu ten, kto kocha przedmiot swej wiary, ciagle musi troszczyć się o to, by nie wyobrażał sobie czegoś fałszywego o Bogu, gdyż wówczas miłość do Niego nie będzie płynęła z czystego serca i wiary nieobłudnej (1Tm 1,5$)$, co oznacza, że po prostu nie będzie miłością ${ }^{68}$. Można zatem uznać, że tak, jak pamiętanie o Bogu i poznawanie Go potrzebuje miłości, dzięki której może do Niego przylgnąć, tak też miłość potrzebuje prawdy o swym przedmiocie, by mogła być sobą. Wewnątrz wiary rozgrywa się więc pewnego rodzaju symbioza rozumu i woli, o której św. Augustyn pisze w następujących słowach:

\footnotetext{
${ }^{63}$ Por. tamże XIII 20, 26, NBA 4, 556, POK 25, 377.

${ }^{64}$ Por. tamże XIV 2, 4 - 3, 5, NBA 4, 566-570, POK 25, 382-383.

${ }^{65}$ Por. tamże XIII 20, 26, NBA 4, 558: „Ex hac fide et tali vita quaecumque notiones sunt in animo fidelis hominis", POK 25, 378.

${ }^{66}$ Por. tamże XIII 20, 26, NBA 4, 556-558, POK 25, 377-378. Zob. A. de Maria, Credo nello Spirito Santo. La Santa Chiesa, Roma 2009, 48; Jaśkiewicz, Św. Augustyn - poszukiwanie Boga, s. 90.

${ }^{67}$ Por. Augustinus, De Trinitate XIV 3, 5, NBA 4, 570, POK 25, 383; tenże, Enchiridion ad Laurentium XXXI 117, CCL 46, 111-112, thum. Budzik, s. 166.

${ }^{68}$ Por. tenże, De Trinitate VIII 4, 6, NBA 4, 336, POK 25, 264; tamże VIII 7, 10, NBA 4, 350 , POK 25, 271.
} 
„Przecież i sama wiara jest tylko myślą połączoną ze zgodą woli. Wszakże nie każdy, kto myśli, wierzy; bo bardzo wielu myśli, ażeby nie wierzyć. Natomiast każdy, kto wierzy, ten myśli, wierząc myśli i myśląc wierzy. [...] bo nie ma wiary bez myślenia ${ }^{69}$.

Wewnątrz triady wiary zachodzi więc swoiste sprzężenie zwrotne, polegające na tym, że im więcej poznaje się Boga, tym bardziej można Go kochać, a z kolei im bardziej się Go kocha, tym wyraźniej można Go poznawać, aż do ujrzenia Go „twarzą w twarz”. Prawda, choćby tylko częściowa, pozwala miłości miłować, zaś miłość, która miłuje przez wiarę, jest warunkiem koniecznym ujrzenia Boga, gdyż przez nią oczyszcza się ludzkie serce stając się zdolnym i godnym tego, by oglądać swego Pana i Oblubieńca ${ }^{70}$. Prawdę tę wyjaśnia Hippończyk w tymi słowami:

„Stąd im goręcej Boga miłujemy, tym pewniej i jaśniej to widzimy. [...] A więc wiara ma w sobie moc, aby nas doprowadzić do poznania i miłości Boga - jako nie całkowicie nieznanego i niedostępnego dla naszej miłości lecz abyśmy Go jaśniej i mocniej umiłowali’”’1.

Oznacza to, że wiara w swym ostatecznym przeznaczeniu prowadzi do pamiętania, rozumienia i kochania nie jakiegoś abstrakcyjnego przedmiotu czy

${ }^{69}$ Tenże, De praedestinatione sanctorum II 5, ed. A. Trapè, NBA 20, Roma 1987, 228: „Quamquam et ipsum credere, nihil aliud est, quam cum assensione cogitare. Non enim omnis qui cogitat, credit, cum ideo cogitent plerique, ne credant; sed cogitat omnis qui credit, et credendo cogitat, et cogitando credit. [...] quoniam fides si non cogitetur, nulla est”, thum. W. Eborowicz: Św. Augustyn, Przeznaczenie świętych, w: Św. Augustyn, Traktaty o tasce. Laska, wiara, przeznaczenie, POK 27, Poznań - Warszawa - Lublin 1971, 268. W związku z tym Szymusiak (Wstęp, s. 25, 30) pisze: „Innymi słowy umysł nasz widzi, ale światłem, które nam pozwala widzieć, jest wiara, człowiek musi posługiwać się wszystkimi siłami swego rozumu, aby pogłębiać to, co mu zostało objawione. Wiara nie zastapi rozumu, ani rozum wiary. Jeśli umysł nie będzie pracował, to niczego nie zobaczy, bo mu wzroku zabraknie; a jeśli wiara nie pokieruje naszym umysłem, to nic nie będzie widoczne z braku światła".

${ }^{70}$ Por. Augustinus, De Trinitate VIII 4, 6, NBA 4, 336, POK 25, 264; Zagórski, Commendavit nobis Dominus oves suas, s. 399-403. Św. Augustyn (De Trinitate VIII 4, 6 - 9, 13, NBA 4, 336-358, POK 25, 263-275) podkreśla, że człowiek może znać i kochać Boga, którego nie widzi, bo jest On mu bliższy i bardziej dla niego obecny niż jakikolwiek kochany i znany przez niego człowiek. Dzieje się tak ze względu na to, że każdy człowiek nosi w sobie obraz Boga i podobieństwo do Niego, które - choć czasami mocno zniekształcone - nigdy nie zostanie w pełni zatarte. Wiara pobudza człowieka do coraz gorętszej miłości przedstawianego przez nią ideału, zaś im bardziej kocha go, tym bliżej niego się znajduje, czyli coraz lepiej go widzi (por. Augustinus, De Trinitate XIV 14, 18 - 16, 22, NBA 4, 594-602, POK 25, 397-401; Desimone, Introduzione alla teologia del Dio Uno e Trino, s. 89-96.

${ }^{71}$ Augustinus, De Trinitate VIII 9, 13, NBA 4, 356-358: ,_...] ut quanto flagrantius diligimus Deum, tanto certius sereniusque videamus [...]. Valet ergo fides ad cognitionem et ad dilectionem Dei, non tamquam omnino incogniti, aut omnino non dilecti; sed quo cognoscatur manifestius et quo firmius diligatur", POK 25, 275. Por. tenże, Enchiridion ad Laurentium II 7-8, CCL 46, 51-52, thum. Budzik, s. 81 . 
wytworzonego lub odkrytego w umyśle ideału, lecz wyłącznie Tego, kogo nie może zobaczyć, a ze wszystkich sił pragnie się poznać poszukując śladów, jakie On zostawia w świecie doczesnym. Jest więc ona stopniem na drodze do mądrości polegającej na uczestnictwie w życiu Boga i przyjęciu Jego światła, dzięki któremu w człowieku wierzącym maleje miłość do świata, a wzrasta umiłowanie rzeczy niewidzialnych ${ }^{72}$. W ten sposób wiara pełni rolę wstępu do autentycznej pobożności oraz umożliwia człowiekowi oddawanie czci prawdziwemu Bogu ${ }^{73}$. To zaś oznacza, że klucz do zrozumienia tkwiącego w niej dynamizmu poszukiwania Boga, znajduje się w obszarze działającej w jej wnętrzu miłości.

\section{WIARA DZIAŁAJĄCA PRZEZ MIŁOŚĆ}

O miłości, również tej, której aktywność można dostrzec w wierze, św. Augustyn wyraża się w następujący sposób:

„Miłość zaś pochodzi od kogoś kochającego i miłością otaczamy jakiś przedmiot. Mamy więc trzy rzeczy w miłości: kochającego, rzecz kochaną i samą miłość. Czym więc jest miłość, jeśli nie pewnym życiem łączącym dwie istoty, albo dążącym do ich złączenia: kochającego i tego, co on kocha?"74

Jawi się ona w świetle powyższych słów Hippończyka jako główna siła pobudzająca dążenie do poszukiwania Boga i umożliwiająca zobaczenie Go w życiu wiecznym. Ze swej natury kieruje się ona bowiem w stronę przedmiotu, gdyż zawsze jest miłością czegoś, co nie jest nią samą ${ }^{75}$. Skoro zatem w wierze funkcjonuje pragnienie poznania wraz z miłością, umożliwiającą miłowanie przez wiarę Tego, który pozostaje dla tej wiary kimś niewidzialnym, to znaczy to, że wiara otwierająca człowieka na objawienie Boga, musi dotyczyć całej jego egzystencji, a nie wyłącznie jakiegoś jej elementu. Człowiek wierzący kocha bowiem - jak wspomniano wyżej - nie tyle wiadomości, jakie posiada o Bogu, ile samego Boga. Wiara działająca przez miłość odsłania się więc jako siła dążąca do nawiązania egzystencjalnej relacji z Tym, w którego wierzy kochając i którego kocha wierząc w Niego, choć Go nie widząc.

Dzieje się tak, gdyż - jak zauważa biskup Hippony - miłość sprawia, że ludzki umysł przywiązuje się (inhaeretur) do tego ideału, który rozpoznaje jako wewnętrzną prawdę, jaką widzi i poznaje w sobie ${ }^{76}$. Kochając zatem ową

${ }^{72}$ Por. tenże, De diversis quaestionibus octoginta tribus, 64, 2-4, CCL 44A, 137-141, thum. Radziejowska, s. 163-167. Zob. Torchia, Contemplazione e azione, ADE, s. 467.

${ }^{73}$ Por. Augustinus, De Trinitate XIV 12, 15, NBA 4, 590-592, POK 25, 395. Więcej na temat rozumienia mądrości przez św. Augustyna zob. Terka, Objawienie Logosu, s. 522-536.

${ }^{74}$ Augustinus, De Trinitate VIII 10, 14, NBA 4, 358: „Amor autem alicuius amantis est, et amore aliquid amatur. Ecce tria sunt: amans, et quod amatur, et amor. Quid est ergo amor, nisi quaedam vita duo aliqua copulans, vel copulari appetens, amantem scilicet, et quod amatur?", POK 25, 276.

${ }^{75}$ Por. tamże VIII 8, 12, NBA 4, 354, POK 25, 273.

${ }^{76}$ Por. tamże VIII 6, 9, NBA 4, 348, POK 25, 270. 
prawdę, człowiek nie chce przyglądać się tylko samemu zwierciadłu, ani też odbijającemu się w nim obrazowi, lecz pragnie zjednoczyć się z samym jego pierwowzorem. Stąd też owo przywiązanie charakterystyczne dla wiary i miłości polega $\mathrm{w}$ swej istocie na woli przylgnięcia do Boga i pragnienia zobaczenia Go, a w swym ostatecznym celu złączenia się z Nim ${ }^{77}$.

W świetle powyższych analiz można wysunąć wniosek, że wiara jest dla św. Augustyna przede wszystkim relacją z Bogiem, a dążenie do poznania Go i poszukiwanie tego, co Boskie w objawiających się zmysłom lub rozumowi znakach, to nie tylko rodzaj inklinacji poznawczej, lecz pragnienie spotkania, gdyż kochać oznacza pragnąć być obecnym dla przedmiotu swej miłości i cieszyć się nim (fruere $)^{78}$. Wiara działająca przez miłość zawiera więc w sobie tak wielkie pragnienie zażyłości z Tym, w którego wierzy i którego kocha, że biskup Hippony nazywa je wprost gwałtem wiary (violentia fidei) ${ }^{79}$.

Tego właśnie poszukiwali wspomniani wyżej Maria Magdalena oraz Tomasz Apostoł, którzy chcieli dotknąć zmartwychwstałego Chrystusa. Z tej perspektywy ich wiara jawi się jako pragnienie dotknięcia Boga realizujące się nie tyle $\mathrm{w}$ intelektualnym oglądzie, który musi być ufundowany na jakiejś głębszej podstawie, ile w spotkaniu i doświadczeniu obecności Boga objawiającego się w Zmartwychwstałym. Dlatego też biskup Hippony może stwierdzić, że wiara streszcza się w Chrystusie, który umarł i zmartwychwstał, aby wyzwolić z mocy diabła pogrążonego w ciemnościach człowieka ${ }^{80}$.

Skoro wiara nie tylko dotyka umysłu człowieka, ale angażuje jego egzystencję, to owo przylgnięcie do Boga musi polegać zarówno na poszukiwaniu Go przez próbę zobaczenia i pokochania, jak i powinno wiązać się z wysiłkiem realizacji poznanych prawd. Miłość funkcjonująca w triadzie wiary, umożliwiając umiłowanie poznanych treści wiary, a zatem także nauk i przykazań Bożych, powoduje bowiem, że człowiek wiąże się również z oglądanym przez siebie ideałem. Tak, jak widząc kogoś sprawiedliwego i rozpoznając samą sprawiedliwość jako coś godnego naśladowania, człowiek pragnie być sprawiedliwym, gdyż kocha sprawiedliwość, tak też dostrzegając ślady Boga $\mathrm{w}$ świecie $\mathrm{i} w$ innych ludziach, chce on również podążać za otrzymaną od Niego nauką ${ }^{81}$. W związku z tym wierzący uczy się patrzeć na świat

${ }^{77}$ Por. tamże XIV 14, 20, NBA 4, 598, POK 25, 399. Zob. N. Cipriani, Molti e uno solo in Cristo. La spiritualità di Agostino, Roma 2009, 194-195.

${ }^{78}$ Por. Augustinus, De Trinitate IX 2, 2, NBA 4, 364-366, POK 25, 279-280. Zob. Bochet, Cuore, ADE, s. 534. Dlatego też św. Augustyn (Confessiones I 1, ed. C. Carena, NBA 3/1, Roma 1965, 4, tłum. Z. Kubiak: Św. Augustyn, Wyznania, Kraków 1996, 23) woła: „Stworzyłeś nas bowiem jako skierowanych ku Tobie. I niespokojne jest serce nasze, dopóki w Tobie nie spocznie". Zob. Jaśkiewicz, Św. Augustyn - poszukiwanie Boga, s. 78.

${ }^{79}$ Por. Augustinus, De fide et operibus XXI 39, NBA 6/2, 758, thum. Budzik, s. 215.

${ }^{80}$ Por. tenże, De Trinitate XIII 20, 25, NBA 4, 554, POK 25, 376.

${ }^{81}$ Por. tamże VIII 6, 9, NBA 4, 346-348, POK 25, 270; tamże XIII 20, 26, NBA 4, 556, POK 25 , 377; tenże, De civitate Dei XXI 16, CCL 48, 782-783, tłum. Kubicki, s. 881-882. 
i oceniać go tak, jak patrzy na niego i ocenia poznawany przez wiarę Mistrz ${ }^{82}$. $\mathrm{W}$ ten sposób realizuje się proces odnowienia (renovatio) zniekształconego przez grzech obrazu Bożego w ludzkiej duszy. Polega on na coraz lepszym poznawaniu Boga, czyli na przechodzeniu od miłości rzeczy doczesnych, cielesnych i widzialnych do umiłowania tego, co wieczne, duchowe, poznawalne jedynie umysłem ${ }^{83}$.

Jeśli jednak - jak zauważa biskup Hippony - „każdy żyje według tego, co kocha" 84 , to owo wewnętrzne przylgnięcie do Boga ludzi duchowych i pragnienie realizacji Jego nauki, musi wyrażać się w zewnętrznych znakach i życiowych postawach. Oznacza to, że wiara działająca przez miłość przyjmuje postać moralnego doskonalenia, które polega w gruncie rzeczy na rozwoju cnót moralnych i miłości bliźniego, a przejawia się w konkretnych czynach miłości ${ }^{85}$.

W tym procesie odnowienia i moralnego doskonalenia rzeczą niezbędną jest wiara, gdyż dzięki niej można dostrzec oraz pokochać ślady Niewidzialnego w doczesności. Dlatego też wszelki rozwój cnót moralnych, takich jak: sprawiedliwość, roztropność, męstwo, czy wstrzemięźliwość, musi odnosić się do wiary, gdyż bez niej nie mogłyby one być prawdziwymi cnotami ${ }^{86}$. Oznacza to, że skoro poprzez moralne życie według Boskiej nauki człowiek może zbliżyć się do Boga, to świętość chrześcijanina zaczyna się od uwierzenia w Chrystusa. Wiara jest bowiem - zdaniem św. Augustyna - konieczna do tego, by móc prowadzić dobre życie. Ona także jest motorem postępu duchowego człowieka, ponieważ sprawia, że może on nieustannie oczyszczać się ze zła i wchodzić w przestrzeń dobra ${ }^{87}$. Hippończyk podkreśla ten fakt stwierdzając: „Wszak poza tą wiarą w Jezusa Chrystusa nikt nie może zostać pojednany z Bogiem, zarówno przed wcieleniem, jak też później""s8.

Tę tezę egzemplifikuje Hippończyk powołując się na postać setnika Korneliusza, który został ochrzczony przez św. Piotra Apostoła. Zauważa bowiem,

\footnotetext{
${ }^{82}$ Por. tenże, De fide et operibus XVII 32, NBA 6/2, 748, thum. Budzik, s. 208.

${ }^{83}$ Por. tenże, De Trinitate XIV 17, 23, NBA 4, 606-608, POK 25, 403-404.

${ }^{84}$ Tamże XIII 20, 26, NBA 4, 556: „[...] secundum hoc enim vivit quisque quod diligit”, POK 25, 378.

${ }^{85}$ Por. tamże VIII 7, 10 - 8, 12, NBA 4, 350-356, POK 25, 271-275. Zob. T.J. van Bavel, Amore, ADE, s. 180-183; Kamczyk, Tota Paschalis Sollemnitas, s. 242; Jaśkiewicz, Św. Augustyn - poszukiwanie Boga, s. 164-165.

${ }^{86}$ Por. Augustinus, De civitate Dei XIX 4, CCL 48, 664-669, tłum. Kubicki, s. 764-768; tenże, De Trinitate XIII 20, 26, NBA 4, 556, POK 25, 378. Zob. G.J. Lavere, Virtù, ADE, s. 1454-1457; Jaśkiewicz, Św. Augustyn - poszukiwanie Boga, s. 142-144.

${ }^{87}$ Por. Augustinus, Enarrationes in Ps. 134, 18, CCL 40, 1950, PSP 42, 128-129; tamże 39, 16, CCL 38, 437, PSP 38, 98-99; tenże, Enchiridion ad Laurentium II 8, CCL 46, 51, thum. Budzik, s. 81; tenże, De diversis quaestionibus octoginta tribus 68, 3, CCL 44A, 177-178, thum. Radziejowska, s. 215. Zob. TeSelle, Fede, ADE, s. 716.

${ }^{88}$ Augustinus, Enarrationes in Ps. 104, 10, CCL 40, 1542: „Non enim quisquam praeter istam fidem quae est in Christo Iesu, sive ante eius incarnationem, sive postea, reconciliatus est Deo", PSP $41,80$.
} 
że ten rzymski oficer żył uczciwie, dawał jałmużny i modlił się, dzięki czemu został uznany za godnego wiary w Chrystusa (por. Dz 10, 4). Nie oznacza to jednak - podkreśla Hippończyk - że Korneliusz był dobrym bez wiary. Musiał posiadać ją w pewnym stopniu, bo gdyby było inaczej, to przecież nie mógłby wzywać Tego, w którego nie wierzyłby. Wiara jest bowiem fundamentem, na którym opiera się cała budowla ludzkich uczynków i wysiłków. Budowanie poza nim byłoby działaniem pozbawionym sensu i przez to bezowocnym ${ }^{89}$.

Możliwość duchowej odnowy, jaka dokonuje się w wierze i dzięki niej, sprawia, że funkcją wiary jest również oczyszczenie ludzkiej duszy, a szczególnie umysłu, tak, by mógł on coraz lepiej dostrzegać obecność Boga i coraz bardziej go miłować ${ }^{90}$. Jeśli jednak wiara jest przede wszystkim spotkaniem z Bogiem i egzystencjalnym doświadczaniem Jego obecności, to również owo oczyszczanie nie może dotyczyć jedynie sfery poznawczej, czyli być wyłącznie usuwaniem wszelkich błędnych wyobrażeń o Bogu, lecz musi dotykać całego człowieka. $Z$ tej racji przybiera ono postać wyzwolenia z niewoli grzechów. One bowiem zaciemniają ludzki umysł utrudniając lub uniemożliwiając mu widzenie Boga oraz poddają człowieka pożądliwości rzeczy doczesnych, przez co zapomina on o swym Stwórcy i Jego obrazie, który nosi w sobie pogrążając się w mrokach niewiary i idolatrii ${ }^{91}$.

Skoro jednak szeroko pojęty błąd w wierze posiada zarówno wymiar epistemologiczny, jak i etyczny, to - jak się wydaje - już możliwość jego istnienia rzuca światło na kolejny jej aspekt. Zdaniem św. Augustyna bowiem, ów błąd wiary polega przede wszystkim na braku rozpoznania Boga w znakach, poprzez które ukazuje się on ludzkiemu rozumowi. Objawia się ono w postaci zatwardziałości serca (obduratio, induratio cordis), które nie jest w stanie pokochać Boga i w zaślepieniu umysłu (caecitatio mentis) niezdolnego do poznania Go. Egzemplifikacją tego rodzaju postawy jest dla biskupa Hippony postać faraona, który nie chciał pozwolić Żydom na opuszczenie Egiptu, domu swej niewoli, pod przewodem Mojżesza. Mimo, że dane mu było oglądać wielkie znaki Bożej mocy, to jednak nie uwierzył Bogu ani nie chciał wypełnić Jego woli ${ }^{92}$.

${ }^{89}$ Por. tenże, De praedestinatione sanctorum VII 12, NBA 20, 244-246, POK 27, 276-277; tenże, De civitate Dei XIX 4, CCL 48, 664, tłum. Kubicki, s. 764. Zob. TeSelle, Fede, ADE, s. 716; Cipriani, Molti e uno solo in Cristo, s. 194.

${ }^{90}$ Por. Augustinus, De Trinitate IV 18, 24, NBA 4, 214, POK 25, 198; tamże XV 23, 44, NBA 4, 700, POK 25, 450. Zob. Torchia, Contemplazione e azione, ADE, s. 466-467; Eckmann, Przebóstwienie czlowieka, s. 143-148.

${ }^{91}$ Por. Augustinus, De Trinitate XIV 12, 15 - 13, 17, NBA 4, 590-594, POK 25, 395-396.

${ }_{92}$ Por. tenże, De diversis quaestionibus octoginta tribus 68, 4-5, CCL 44A, 179-182, thum. Radziejowska, s. 217-221; tenże, De vera religione X 18, CCL 32, 199, thum. Ptaszyński, s. 92-93. Św. Augustyn podkreśla, że ten, kto nie chce uwierzyć w Chrystusa aż do końca życia, winien jest grzechu przeciw Duchowi Świętemu, który nie może być odpuszczony. Podstawowym zaś wymiarem grzechu przeciw wierze jest odrzucenie Chrystusa. W innym miejscu natomiast (De utilitate credendi XI 25, ed. A. Pieretti, NBA 6/1, Roma 1994, 216-217, thum. J. Sulowski: Św. Augustyn, 
Przykład egipskiego władcy i wielu innych postaci, które nie uwierzyły Bogu, pokazuje, że wiara nie jest czymś przynależnym do natury człowieka, gdyż wówczas wszyscy ludzie byliby wierzącymi. Skoro zaś może ktoś nie uwierzyć w Boga, to znaczy, że wiara jest raczej zaproszeniem do relacji i spotkania niż koniecznością o wymiarze ontologicznym ${ }^{93}$. Możliwość odrzucenia tego zaproszenia zakłada jednak jego wcześniejsze istnienie oraz skierowanie go w stronę człowieka. Dlatego też, choć wiara wymaga od tego, kto ją posiada, zaangażowania umysłu i woli, to jednak - jak się wydaje - zdaniem św. Augustyna jej pojawienie się nie zależy wyłącznie od ludzkiej decyzji, lecz przychodzi z zewnątrz, od Tego, który najpierw pozwala się poszukiwać, poznawać i kochać. Analiza zjawiska wiary nie może więc pominąć tego istotnego dla niej aspektu.

\section{WIARA DAREM ŁASKI}

Skoro wiara może pojawić się w umyśle człowieka, ale może również w nim nie zaistnieć lub z niego zniknąć, to należy przyjąć, że posiada ona swój początek oraz koniec. Jej kresem może być widzenie Boga „twarzą w twarz”, które nastapi dopiero w wieczności i będzie wyrazem pełnej szczę́́liwości ofiarowanej człowiekowi. Tam bowiem, gdzie jest widzenie, nie potrzebna jest już wiara. W umyśle ludzkim pozostanie wówczas - jak uważa św. Augustyn wspomnienie dawnej wiary pozostawione w pamięci ${ }^{94}$. Innym kresem wiary może być jej porzucenie przez człowieka będące skutkiem braku wytrwałości ${ }^{95}$.

Istota wiary, która ze względu na możliwy swój kres, okazuje się być rzeczywistością zmienną i ograniczoną do doczesności, odsłania się jednak bardziej w jej początku. Biskup Hippony, rozważając to zagadnienie, przyznaje się do pewnej ewolucji poglądów, jaka się w nim dokonała pod wpływem zgłębiania Pisma Świętego. Uznawał bowiem najpierw za prawdziwą opinię głosząca, że skoro wiara rodzi się ze słuchania słowa Bożego, to jest ona po prostu odpowiedzią, jakiej udziela człowiek przyjmując głoszoną mu Ewangelię $^{96}$. Potem jednak Hippończyk odrzucił to wyjaśnienie, uznając, że nie jest ono wystarczające i znajduje się zbyt blisko herezji pelagiańskiej ${ }^{97}$. Przywołu-

O pożytku wiary, PSP 54, 54) Hippończyk dodaje, że również wiara może być czymś nagannym wówczas, gdy wierzy się w coś niegodnego Boga, albo wykazuje się łatwowierność w kontaktach z ludźmi. Zob. tenże, De fide et operibus XVI 30, NBA 6/2, 744, tłum. Budzik, s. 206, tamże XXI 39 - XXI 41, NBA 6/2, 758-759, tłum. Budzik, s. 215-217; tamże XXIII 44, NBA 6/2, 764, thum. W. Budzik, s. 220.

${ }^{93}$ Por. tenże, De diversis quaestionibus octoginta tribus 68, 5, CCL 44A, 180-182, thum. Radziejowska, s. 221; tenże, De praedestinatione sanctorum III 7, NBA 20, 234, POK 27, 271.

${ }^{94}$ Por. tenże, De Trinitate XIV 3, 5, NBA 4, 568-570, POK 25, 383-384.

${ }^{95}$ Por. tenże, De correptione et gratia VII 12, ed. A. Trapè - M. Palmieri - F. Monteverde, NBA 20, 132-134, tłum. W. Eborowicz: Św. Augustyn, Nagana a łaska, POK 27, 177.

${ }^{96}$ Por. tenże, De praedestinatione sanctorum III 7, NBA 20, 230-134, POK 27, 269-271.

${ }^{97}$ Por. tamże II 3, NBA 20, 224-226, POK 27, 266. 
jąc bowiem fragment Listu św. Pawła do Tesaloniczan (1Tes 2, 13), w którym Apostoł dziękuje Bogu za wiarę adresatów, biskup Hippony stwierdza:

„Czyż w Pierwszym Liście do Tesaloniczan nie mówi się o początku ich wiary, za co dziękuje tenże Apostoł w słowach: «Dlatego nieustannie dzięki czynimy Bogu, że skoroście przyjęli głoszone przez nas słowo Boże, przyjęliście je nie jako słowo ludzkie, ale - jak jest w istocie-jako słowo Boże. Działa też ono w nas wierzących». Dlaczego św. Paweł dziękuje Bogu? Dziękczynienie byłoby próżne i czcze, gdyby Apostoł nie dziękował rzeczywistemu dobroczyńcy. Lecz ponieważ dziękczynienie Pawłowe nie jest ani czcze, ani próżne, zaiste sam Bóg, któremu dzięki składa jest sprawcą przyjęcia przez Tesaloniczan głoszonego za pośrednictwem Apostoła słowa Bożego. [...] Bóg działa w sercach ludzi, wzywając ich według wyroku swego"98.

Początek wiary jest więc darem Boga, który sam rozbudza ją w sercu człowieka, a nie wyłącznie rezultatem starań głosiciela Ewangelii i dobrej woli słuchającego $0^{99}$. Biskup Hippony podkreśla więc za św. Pawłem (por. 1Kor 3, 5-7), że nie jest ważny ten, kto sieje, ani ten, kto podlewa, lecz jedynie Bóg, który daje wzrost. Oznacza to, że cokolwiek człowiek posiada, otrzymuje od swego Stwórcy, więc w rzeczywistości nie posiada niczego, czego by nie otrzymał (por. 1Kor 4, 7) ${ }^{100}$. Nawet bowiem wola uwierzenia, czyli odpowiedź człowieka za dar wiary, jest również darem Bożym ${ }^{101}$. Dlatego też św. Augustyn, posługując się wspomnianym wyżej porównaniem wiary do fundamentu budowli, przypomina za Psalmista, że jeśli Pan domu nie zbuduje, to wszelkie ludzkie wysiłki pozostaną daremne (por. Ps 127, 1). Z tego powodu wiara jest rozumiana przez Hippończyka jako dzieło Boże (opus Dei), przygotowane po to, by ludzie mogli je pełnić (por. J 6, 28-29) ${ }^{102}$.

${ }^{98}$ Tamże XIX 39, NBA 20, 290: „,...] nonne initium fidei apparet Thessalonicensium, de quo tamen idem Apostolus Deo gratias agit, dicens: «Propterea et nos gratias agimus Deo sine intermissione, quoniam cum percepissetis a nobis verbum auditus Dei, excepistis non ut verbum hominum, sed sicut est vere verbum Dei, quod operatur in vobis, cui credidistis» (1Tes 2, 13)? Quid est quod hinc Deo gratias agit? Nempe vanum est atque inane, si cui gratias agit, hoc ipse non fecit. Sed quia hoc vanum et inane non est, profecto Deus cui de hoc opere gratias agit, ipse fecit, ut cum percepissent ab Apostolo verbum auditus Dei [...]. Deus igitur operatur in cordibus hominum, vocatione illa secundum propositum suum", POK 27, 301-302.

${ }^{99}$ Por. tamże II 6, NBA 20, 230, POK 27, 268.

${ }^{100}$ Por. tamże IV 8-V 9, NBA 20, 236-240, POK 27, 272-274.

${ }^{101}$ Por. tamże VI 11, NBA 20, 242-244, POK 27, 275. Prawdę tę podkreśla również - jak zauważa biskup Hippony - praktyka Kościoła, który modli się nie tylko za wiernych, by wzrastali w wierze, ale także za wszystkich niewierzących oraz tych, którzy nie chcą wierzyć lub mają nawet w stosunku do wiary negatywne nastawienie, aby obdarzeni zostali łaską, mogli uwierzyć; zob. tenże, De dono perseveratiae III 6, ed. A. Trapè, NBA 20, 308-310, thum. W. Eborowicz: Św. Augustyn, Dar wytrwania, POK 27, 339; tenże, De gratia et libero arbitrio XIV 29, ed. A. Trapè, NBA 20, 62, thum. W. Eborowicz: Św. Augustyn, Easka $i$ wolna wola, POK 27, 130-131.

${ }_{102}$ Por. tenże, De praedestinatione sanctorum VII 12, NBA 20, 244-246, POK 27, 276; tenże, Enchiridion ad Laurentium XVIII 68 CCL 46, 86-87, tłum. Budzik, s. 130. Darmowość łaski i pry- 
Skoro zatem Bóg rozbudza w ludzkim sercu wiarę, to znaczy rozpala w nim pragnienie poznania i kochania Go, czyli ciagłego poszukiwania i odkrywania Jego śladów w doczesnych, zarówno materialnych, jak i duchowych znakach, by w ten sposób doprowadzić człowieka do spotkania ze Sobą, to można stwierdzić, że początek owej wiary odsłania się jako szczególne wybranie, wezwanie i powołanie (vocatio) do bycia z Bogiem ${ }^{103}$. Św. Augustyn ilustrując tę tezę słowami samego Chrystusa, który według relacji św. Jana, oznajmił, iż warunkiem przyjścia do Niego, czyli wiary, jest usłyszenie głosu Ojca, pisze o tym następująco:

„Kiedy zatem głosi się Ewangelię, jedni wierzą, inni nie wierzą. Wierzący, kiedy zewnątrz brzmią słowa kaznodziei, słyszą w sobie głos Ojca i od Niego się uczą; niewierzący zaś słyszą zewnątrz słowa wypowiadane, ale w sobie ani nie słyszą głosu Ojca, ani od Niego się nie uczą. To znaczy, że Bóg jednym daje wiarę, a innym jej nie daje [...]. Kogo zatem Ojciec pociaga do Chrystusa i kto usłyszy od Ojca wezwanie, by przyjść do Chrystusa, ten otrzymuje od Ojca dar wiary w Chrystusa. Chrystus nie wyróżnia słuchających Ewangelię od niesłuchających jej, ale wierzących od niewierzących, kiedy powiada: «Nikt nie może przyjść do Mnie, jeśliby mu nie było dane od Ojca mego» (J 6, 65). Zatem wiara - zarówno jej zapoczątkowanie, jak i doskonałość - jest darem Boga"104.

Wiara jest więc wezwaniem skierowanym do ludzi nie dlatego, że uwierzyli, lecz aby uwierzyli. Gdyby bowiem - jak zauważa św. Augustyn

mat wiary nad wszelkimi czynami ludzkimi, nie oznacza jednak tego, że uczynki są zupełnie niepotrzebne. Takie mniemanie nazywa św. Augustyn wiarą martwą (fides mortua), właściwą diabłu (fides daemonum). Usprawiedliwienie przez wiarę odnosi się tylko do tego, że człowiek nie może w żaden sposób zasłużyć na łaskę przebaczenia i usprawiedliwienia, lecz otrzymuje ją darmo, jako pomoc daną przez Boga do przezwyciężania złych pożądliwości. Łaska ta nie przekreśla jednak uczynków, gdyż - jak zauważa Hippończyk - ten sam Apostoł, który głosił usprawiedliwienie przez samą wiarę, naucza też o potępieniu tych chrześcijan, którzy uwierzywszy w Chrystusa i przyjąwszy dar chrztu świętego, żyją w sposób daleki od nauki Zbawiciela, popełniając rozmaite zbrodnie (por. 1 Kor 6, 9-10). Miłowanie świata i pożądanie tego, co oferuje jest bowiem nieuczciwością i błędem, w jaki wpadają chrześcijanie, a co za tym idzie, również zaprzeczeniem wiary, która uczy zachowywać Boże przykazania; por. Augustinus, Enchiridion ad Laurentium XVIII 67, CCL 46, 85-86, thum. Budzik, s. 129; tenże, De fide et operibus VIII 13, NBA 6/2, 712-714, tłum. Budzik, s. 184.

${ }^{103}$ Por. tenże, De praedestinatione sanctorum III 7, NBA 20, 234, POK 27, 271. Zob. Bavel, Amore, ADE, s. 185; Špidlik - Gargano - Grossi, Duchowość Ojców Kościoła, s. 363-364.

${ }^{104}$ Augustinus, De praedestinatione sanctorum VIII 15-16, NBA 20, 250-252: „Cum igitur Evangelium praedicatur, quidam credunt, quidam non credunt; sed qui credunt, praedicatore forinsecus insonante, intus a Patre audiunt atque discunt; qui autem non credunt, foris audiunt, intus non audiunt neque discunt: hoc est, illis datur ut credant, illis non datur. [...] Ergo trahi a Patre ad Christum, et audire ac discere a Patre ut veniat ad Christum, nihil aliud est, quam donum accipere a Patre, quo credat in Christum. Neque enim audientes Evangelium a non audientibus, sed credentes a non credentibus discernebat qui dicebat: «Nemo venit ad me, nisi fuerit ei datum a Patre meo» $(\mathrm{J} 6,65)$. Fides igitur, et inchoata, et perfecta, donum Dei est”, POK 27, 279-280. 
- kryterium wyboru grona Apostołów przez Chrystusa była ich wiara w Niego, to oznaczałoby to, że to oni pierwsi Go wybrali i dlatego zasłużyli na Jego wybranie. Tymczasem ich decyzja pójścia za Chrystusem była pochodną pierwotnego wyboru, jakiego dokonał wcześniej Mistrz z Nazaretu ${ }^{105}$. Skoro zaś ten dar jest uprzedni wobec zaangażowania ludzkiej woli zarówno w wymiarze wewnętrznym, jak i zewnętrznym, a więc dokonuje się bez żadnych zasług ze strony człowieka, to jest on przejawem łaski Bożej, czyli darem danym zupełnie darmo i udzielanym według Bożego wyboru, będącym wyrazem Jego miłosierdzia ${ }^{106}$. Łaską jest także wytrwanie w wierze oraz jej zewnętrzne wyznawanie ${ }^{107}$.

Jeśli zatem zarówno początek wiary, jak i proces jej doskonalenia, czyli poszukiwanie Boga, by Go coraz lepiej poznać i kochać, zależy od daru Bożego powołania, to warunkiem koniecznym do jej zaistnienia w duszy człowieka jest dążenie Boga do zawiązania pewnego rodzaju wspólnoty z człowiekiem. Spotkanie między nimi jest zatem możliwe dopiero wówczas, gdy Bóg pozwoli się poszukiwać, odkrywać, poznawać i kochać, a przez to zaprosi człowieka do wspólnoty ze sobą.

Tego otwarcia na człowieka nie należy jednak rozumieć jako biernego oczekiwania na odkrycie przez ludzki umysł swego Stwórcy, gdyż - zgodnie z myślą św. Augustyna - inicjatywa spotkania może wyjść jedynie od Boga. On zatem nie tylko pozwala się poznawać i kochać, lecz sam najpierw obdarza człowieka miłością i poszukuje zagubionego w ciemnościach grzechu, wzywając go do nawrócenia i wiary, a nawet uzdalnia go do usłyszenia tego wezwania i pójścia za jego głosem. Stąd też człowiek może poprzez wiarę poszukiwać Boga, pamiętać o Nim i kochać Go tylko dlatego, iż został przez Niego uprzednio poznany i pokochany, a dzięki temu zaproszony do uczestnictwa (participatio) w Nim ${ }^{108}$. Wiara, która rodzi się z usłyszenia tego zaproszenia

${ }^{105}$ Por. tamże XVII 34, NBA 20, 282, POK 27, 297.

${ }^{106}$ Por. tenże, De dono perseverantiae XII 28, A. Trapè, NBA 20, 340-342, POK 27, 354; tenże, Enchiridion ad Laurentium XXVIII 107, CCL 107, tłum. Budzik, s. 159. Niezależność Bożego wyboru, przyjmowana przez św. Augustyna w celu podkreślenia darmowości i uprzedniości łaski względem jakichkolwiek zasług ludzkich, wiąże się w problemem przeznaczenia. Jeśli bowiem zarówno wiara, jak i dobre uczynki człowieka, same w sobie nie mają wartości zasługującej na zbawienie, a nawet nie mogą zaistnieć, jeśli nie towarzyszy im łaska Boża, to oznacza to, że zależą one jedynie od zupełnie wolnego wyboru Bożego. Darmowość wolnego wyboru Boga uzasadnia biskup Hippony powołując się na Jego miłosierdzie i sprawiedliwość. Wszyscy ludzie bowiem skutkiem grzechu pierworodnego są masą grzeszników skazanych na potępienie, tymczasem Bóg w swoim miłosierdziu wybiera tych, których zechce i których przeznacza do zbawienia, i udziela im daru wiary, by mogli Go poszukiwać i znaleźć. Wybór ten jest okazaniem miłosierdzia, więc pozostali ludzie, nie wybrani przez Boga, a więc skazani na potępienie, spotykają się tylko z Bożą sprawiedliwością i karą, na którą zasłużyli; zob. tenże, De dono perseverantiae XII 28-29, NBA 20, 340-342, POK 27, 354-355; tenże, De praedestinatione sanctorum XVII 34, NBA 20, 282, POK 27, 297-298; tamże X 20, NBA 20, 258, POK 27, 284.

${ }^{107}$ Por. tenże, De dono perseverantiae XIX 50, NBA 20, 376-378, POK 27, 373.

${ }^{108}$ Por. tenże, De Trinitate XIV 14, 18, NBA 4, 596, POK 25, 397. Zob. TeSelle, Fede, ADE, 
(por. Rz 10,17) w swej najgłębszej istocie polega zatem na tym, by człowiek uwierzył miłości Boga ofiarowanej mu bez żadnej jego zasługi ${ }^{109}$.

Patrząc z tej perspektywy na zagadnienie wiary św. Augustyn odsłania jej najbardziej podstawową warstwę. Nie jest ona bowiem jedynie aktem człowieka, rzeczywistością rozgrywającą się w jego świadomości, ale jest przede wszystkim darem udzielanym przez objawiającego się Boga, który pragnie wynieść człowieka do bliskiej relacji ze Sobą. Taki sens otrzymują wszystkie epifanie biblijne, czy też odkryta przez biskupa Hippony, a istniejąca w rozumnej duszy, triada pamiętania, oglądania i kochania Boga. Wyrazem tego powołania i wybrania Bożego jest również pozwolenie dotknięcia udzielone Tomaszowi przez Zmartwychwstałego Pana oraz pragnienie dotknięcia Go, jakie stało się udziałem Marii Magdaleny. Motyw Bożej miłości znajduje się także u podstaw wydarzenia (a nawet wręcz umożliwia je), w którym streszcza się cała wiara, czyli - jak wspomniano wyżej - w tajemnicy wcielenia. Św. Augustyn pisze o tym następująco:

„Ten, który z natury był Synem Bożym, wzruszony miłosierdziem względem synów ludzkich, stał się Synem Człowieczym [...]. Jeśli to się mogło stać, to bardziej prawdopodobne się wydaje, by ci, którzy z natury są synami człowieczymi, przez łaskę Boga stali się synami Bożymi i mieszkali w Bogu, w którym i przez którego jedynie mogą być szczęśliwi, zyskując uczestnictwo w Jego nieśmiertelności. Właśnie dla przekonania nas o tym, Syn Boży przyjął uczestnictwo w naszej śmiertelności” ${ }^{110}$.

Dlatego więc człowiek przez wiarę uczy się odkrywać to, co niewidzialne i wieczne, by mógł mieć udział w nieśmiertelności Boga i stać się Jego dzieckiem. Oznacza to, że ze swej istoty prowadzi ona do usprawiedliwienia człowieka, czyli odnowienia zatartego przez grzech, ale ciągle istniejącego w jego duszy, podobieństwa do Boga, a tym samym musi być rozumiana jako droga prowadząca do doskonałości duchowej ${ }^{111}$. Wiara, która stoi u początków poszukiwania Boga przez człowieka oraz umożliwia mu poznawanie i miłowa-

s. 715-716; Cipriani, Molti e uno solo in Cristo, s. 194; Zagórski, Commendavit nobis Dominus oves suas, s. 384-388; de Maria, Credo nello Spirito Santo, s. 101; Eckmann, Przebóstwienie człowieka, s. $130-137$.

${ }^{109}$ Por. Augustinus, De Trinitate XIII 10, 13, NBA 4, 528, POK 25, 363.

${ }^{110}$ Tamże XIII 9, 12, NBA 4, 528: „Si enim natura Dei Filius propter filios hominum misericordia factus est hominis filius; [...] quanto est credibilius, natura filios hominis gratia Dei filios Dei fieri, et habitare in Deo, in quo solo et de quo solo esse possunt beati participes immortalitatis eius effecti; propter quod persuadendum Dei Filius particeps nostrae mortalitatis effectus est?", POK 25, 362.

${ }^{111}$ Por. tenże, Enchiridion ad Laurentium I 5, CCL 46, 50, thum. Budzik, s. 79; tenże, De Trinitate XIV 16, 22-17, 23, NBA 4, 602-608, POK 25, 401-404; tenże, De diversis quaestionibus octoginta tribus 69, 9, CCL 44A, 192-194, thum. Radziejowska, s. 237; tenże, Contra Faustum Manichaeum XVI 29, PL 42, 335-336, PSP 55, 172. Zob. TeSelle, Fede, ADE, s. 716; Torchia, Contemplazione e azione, ADE, s. 467; Cipriani, Molti e uno solo in Cristo, s. 193-195; Zagórski, Commendavit nobis Dominus oves suas, s. 366. 
nie tego, co wieczne, pomimo tego, że nie odsłania tajemnicy Stwórcy, to sprawia, że staje się On dla człowieka, choć niewidzialny, ale jednak bliski.

Analiza wewnętrznej struktury wiary odsłania ją jako pragnienie zobaczenia siłami umysłu tego, w co się wierzy, a co człowiek rozpoznaje jako wieczne, niezmienne i znajdujące się ponad nim. W tym pragnieniu zawiera się zarówno poznanie doktryny i Bożych przykazań, jak również próba doświadczenia obecności Boga i spotkania z Nim. Wiara jest więc w swej istocie osobową relacją zachodzącą pomiędzy człowiekiem, który pamięta o Bogu, poznaje Go w pewnym stopniu i kocha, a Bogiem występującym nie tylko jako ten, kto pozwala się poszukiwać, poznawać i kochać, lecz przede wszystkim jako miłosierny Zbawiciel, który miłując człowieka, obdarza go łaską wiary, by uświęcić go i otworzyć przed nim drogę do komunii ze Sobą. Dlatego też w wyznaniu, jakie ludzie składają swemu Stwórcy, ważne jest zarówno to, że wierza, jak również to, że wierzą w Boga, gdyż to On jest źródłem wszelkiej wiary, a każda wiara w Nim dopiero nabiera głębszego sensu i wartości.

\section{FAITH AS A QUEST FOR GOD \\ IN THE LIGHT OF ST. AUGUSTINE'S TEACHING}

\section{(Summary)}

For St. Augustine the act of faith, that exists in the mind of a believer, is an intentional phenomenon with a content related to the unseen, and eventually, to God. Since human mind cannot see the object of faith, it can be unveiled only through visible signs. Their role is played in biblical Revelation by wordly goods and mundane matters, which are used by God to show Himself. In an inner experience this role is played by the triad of memory, contemplation and love, thanks to which a person can remember about God, know Him, and love Him. However, God does not evince himself fully neither in external signs nor in the rational soul, created in His own image and likeness. Therefore, faith brings out the quest for God, in which the main power that kindles a desire to see God is love. Thus, faith is a desire for an encounter, that begins thanks to the grace of God. And God, who is guided by love, calls human to the close relationship with himself. Accordingly, faith consists in human's belief in the love of God, given without any credit.

Key words: God, human, grace, love, revelation, memory, quest for God, vocation, cognition, reason, things unseen, faith, signs.

Słowa kluczowe: Bóg, człowiek, łaska, miłość, objawienie, pamięć, poszukiwanie Boga, powołanie, poznanie, rozum, rzeczy niewidzialne, wiara, znaki. 